\title{
The proliferation of multilateral development banks
}

\author{
Miles Kellerman ${ }^{1}$
}

Published online: 28 February 2018

(C) The Author(s) 2018, corrected publication March/2018

\begin{abstract}
Since 1945 the number of multilateral development banks (MDBs) has increased at a linear rate, with approximately one new MDB created every three years. The proliferation of MDBs has resulted in an inefficient duplication of international institutions with overlapping functions. Further, this trend contradicts our existing understanding of why states create countervailing international organizations. This article proposes a novel, two-step theoretical model of institutional change and creation in an attempt to explain this empirical puzzle. Utilizing the complementarities of rational-choice and historical institutionalism, the model demonstrates that the rational actions of states in the past can lead to seemingly irrational institutional change in the future. This process results in the repetitive creation of countervailing MDBs designed to solve the same functional problems. To evaluate the model's hypotheses, three case studies are undertaken, employing archival material, internal documents, and 48 interviews conducted by the author in London, Washington, D.C. and Manila, Philippines. The empirical results are of direct interest to policy-makers currently negotiating the structure of new MDBs in Asia and Latin America.
\end{abstract}

Keywords Institutional design · Historical institutionalism · Regime dynamics · Economic development · Multilateral development banks

On July 15th, 2014, the leaders of Brazil, Russia, India, China and South Africa (colloquially termed 'BRICS') announced the creation of the New Development Bank (NDB). The creation of the NDB was widely celebrated as a long-awaited challenge to what is perceived to be a Western-dominated World Bank. It reflects BRICS nations' dissatisfaction with their positions within the existing institution, in which they collectively share just $13.2 \%$ of total voting power despite accounting for approximately $22 \%$ of world Gross Domestic Product (World Bank 2016a, b). Further, the NDB will purportedly provide much-needed capital for infrastructure, free from the shackles of

Miles Kellerman

miles.kellerman@univ.ox.ac.uk

1 University of Oxford, Oxford, UK 
the World Bank's infamously slow, bureaucratic and conditional lending process (Romani et al. 2012). As the editorial board of Chinese state-owned news agency Xinhua (2014) summarized, "The plans of the emerging-market bloc of BRICS to establish a development bank ushers in a long-awaited and helpful alternative to the Western-dominated institutes in global finance."

The New Development Bank is not, however, so new. In fact, every region represented by BRICS has a development bank of its own, each of which was created out of dissatisfaction with the World Bank. The Inter-American Development Bank (created in 1959), African Development Bank (1963) and Asian Development Bank (1966) were a direct response to developing nations' unhappiness with the supply of loans available from, and their lack of voice within, the existing institution. As John White (1970: 29) wrote of the regional MDBs in the early 1970s, "[their creation] is essentially an act of political resistance against the developed countries' hegemony in the world economy." This is a remarkably similar sentiment to the one expressed by Xinhua over 40 years later. If the original regional MDBs were a reaction to the Western-dominated World Bank, why would BRICS need to create yet another countervailing institution?

If we take a closer look at the full landscape of MDBs, the puzzle only deepens. Since the creation of the World Bank in 1945, the number of MDBs has increased at a linear rate, with approximately one new bank created every three years (Fig. 1). This proliferation (and subsequent functional overlap) challenges our understanding of why states create countervailing institutions and how those institutions subsequently develop over time. Further, it raises a number of practical and normative concerns. First, has proliferation led to a violation of the 'additionality' principle? MDB assistance must be provided as a necessary addition to, rather than as a replacement of, other sources of financing (EBRD 2012: 3). Proliferation may, however, lead to unnecessary investment, crowding out private sector loans. Second, does competition among MDBs lead to a deregulatory spiral, in which banks are incentivized to lower social, environmental or transparency standards in order to attract borrowers? ${ }^{1}$ Third, does MDB proliferation create new issue linkages in negotiations, and how does that affect the balance of power between lending and borrowing member states? ${ }^{2}$ Despite these concerns, there has not been a single attempt within political science, economics, sociology or related disciplines to explain the underlying trend. This article will attempt to fill this gap, and thus is guided by the following research question: what explains the proliferation of MDBs?

\section{Previous explanations of countervailing creation and MDB dynamics}

In an attempt to explain the proliferation of MDBs, this article presents a novel theoretical model of institutional change and creation. This model builds upon a number of previous contributions, which can be roughly separated into two groups. The first group concerns previous work in international relations, political economy and industrial organization on how and why actors create countervailing institutions.

\footnotetext{
${ }^{1}$ On deregulatory spirals, see Genschel and Plümper (1997).

${ }^{2}$ See Mikulaschek (2017) for a review of the relevant literature and an analysis of issue linkages between the European Union and the United Nations Security Council.
} 


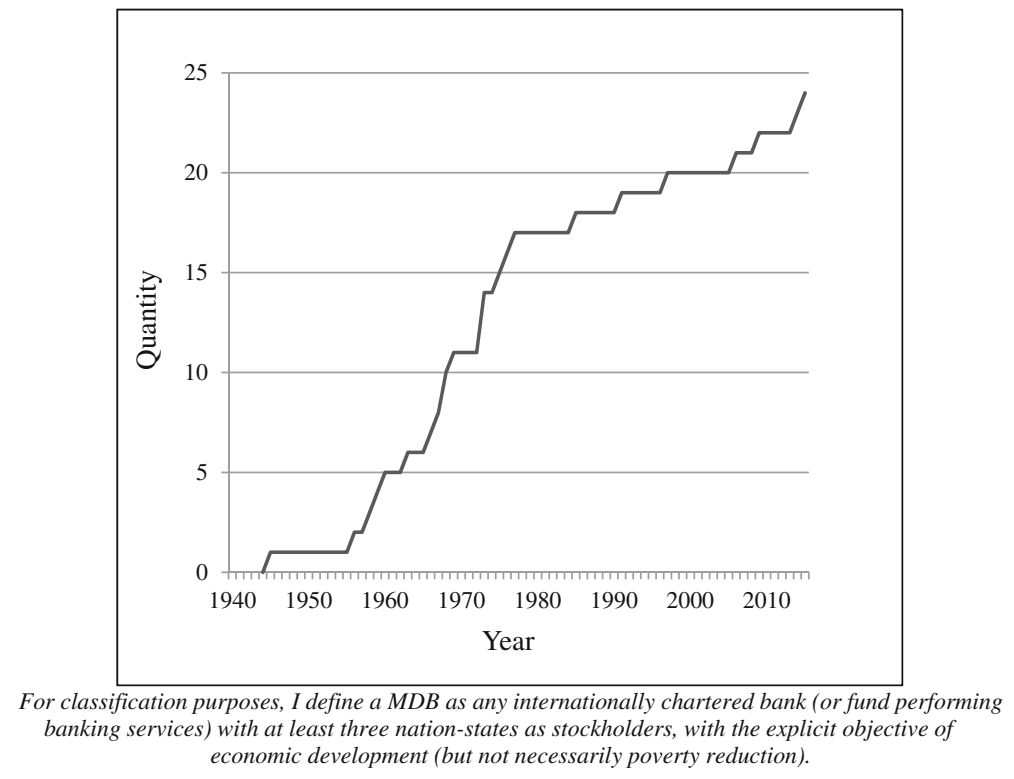

Fig. 1 Proliferation of MDBs

Second, there is a very small group of studies that examine regional MDBs from an institutional perspective. This section will review the capacity of existing theories to address the empirical puzzle of interest and explain why a new theoretical model is necessary.

\subsection{Studies of countervailing institutional creation}

The predominant view within international relations is that nation-states create institutions to further their own interests (Abbott and Snidal 1998; Koremenos et al. 2001). When those institutions fail to sufficiently serve those interests, dissatisfied states will naturally desire change (Young 1982). Often, however, change is not possible. This may be because past decisions constrain the negotiating powers of dissatisfied actors in the present and/or they lack the resources desired by other members, and thus lack leverage (Pfeffer and Salancik 1978; Pierson 2000, 2004). In such situations, states may seek to create an alternative, countervailing institution. The theoretical model presented in this article is directly concerned with the strategic dynamics of this decision.

The contemporary study of countervailing institutional creation can be most accurately traced to Albert Hirschman's (1972) Exit, Voice and Loyalty. Hirschman's insights have in recent years inspired a burgeoning literature on institutional creation in response to dissatisfaction with the status quo. Jupille et al. (2013) provide the most comprehensive analytical framework of this process, arguing that dissatisfied actors with bounded rationality will attempt, in order of necessity, to select a different institution; change the existing institution; or, as a last resort, create an alternative. Morse and Keohane (2014) introduce a complementary concept of 'contested multilateralism,' which is defined as situations in which "states and/or non-state actors either shift their focus from one existing institution to another or create an alternative 
multilateral institution to compete with existing ones" (Ibid: 387). The merits of 'contested multilateralism' as an analytical concept have subsequently been discussed at length in a recent issue of Global Constitutionalism (see de Búrca 2016; Follesdal 2016; Keohane and Morse 2016; Kreuder-Sonnen and Zangl 2016; Walker 2016). And, finally, Urpelainen and Van de Graaf (2014) present a formal model of a bargaining game between coalitions to explain institutional overlap, with high priority placed on domestic political pressures as a predictor of countervailing creation.

The model presented here builds on these contributions to address an empirical phenomenon that existing theories cannot (and did not originally seek to) explain. Jupille et al. (2013) and Morse and Keohane (2014) outline the conditions under which they expect dissatisfied actors to create new, countervailing institutions. These approaches may be sufficient to explain the creation of a single countervailing institution (e.g., the NDB vis-à-vis the World Bank). But they do not explain why coalitions of states would continue to create numerous overlapping countervailing institutions over time (e.g., the ADB and Asian Infrastructure Investment Bank vis-à-vis the World Bank). This is, however, an empirical puzzle that neither work seeks to address. Therefore, the model presented here should be interpreted as a complementary extension of these analytical frameworks rather than as a competitor. Specifically, it contributes to the existing literature by arguing that the conditions under which countervailing creation occurs will affect the future development of new institutions and the likelihood of further proliferation. This argument is consistent with a growing recognition that rational-choice and historical institutionalism can be fruitfully combined (see Section 2).

\subsection{Studies of regional MDBs}

The literature on regional MDBs is sparse. Those empirical studies that do exist tend to concentrate on the determinants of MDB lending patterns (e.g., Rodrik 1996; Gutner 2002; Prada 2012; Basílio 2014). Scholars have also analyzed MDB internal politics, compared their governance structures, and studied the formulation of internal coalitions (respectively: Krasner 1981, 1985; Woods 1999; Lyne et al. 2009). Further, previous studies have indirectly addressed institutional overlap by analyzing the capacity of borrowers to 'forum shop' between competing development banks (Avalle 2005; Humphrey and Michaelowa 2013). Diamond (1957) and White (1970) provide early commentaries on the institutional 'style' of MDBs, but published too early to observe their subsequent proliferation.

In recent years a small group of scholars have assessed regional MDBs from an institutional perspective. These works are rooted in the widely-held observation that MDBs are resource-dependent organizations (Pfeffer and Salancik 1978). Most studies treat shareholder action as the primary determinant of institutional change. Babb (2009), for example, provides a thorough descriptive analysis of how the United States used its position as a major contributing shareholder to influence the policies, procedures and lending decisions of regional MDBs. Such perspectives ascribe, I posit, considerable causal power to the agency of actors. Humphrey (2016) offers an important alternative perspective, finding that the World Bank, IADB and Andean Development Corporation (CAF) converged toward a single organizational model in order to maintain access to international bond markets. This article shares certain 
characteristics with deterministic arguments that deny or de-emphasize actor agency. It implies that international financial markets exert a homogenizing effect on MDBs' institutional form regardless of other variables such as the composition of shareholders (Ibid: 94).

The theoretical model presented here places agency at the center of the analysis, arguing that institutional creation and change are the result of strategic interaction between (imperfectly) rational actors. Although this approach differs from Humphrey's (2016) perspective, the model shares his observation that MDBs must make themselves sufficiently attractive to private market participants (e.g., bondholders) in order to access capital markets. It does not, however, conceptualize this requirement as a structural, homogenizing force with deterministic tendencies. Rather, it is incorporated into an agency-based model of strategic interaction in an attempt to explain the phenomenon of interest. In so doing, this article contributes to the theoretical debate over MDB institutional dynamics. It is, to the author's knowledge, the first attempt to construct and empirically evaluate falsifiable hypotheses of institutional creation and change with respect to regional MDBs. Unlike previous works that have been largely descriptive, the argument presented here seeks to be explanatory. ${ }^{3}$

\section{Cyclical institutional change and creation}

To address the empirical puzzle, I present a novel theory of cyclical institutional change and creation. The argument focuses on the objectives of nation-state coalitions, consistent with the rational actor model (RAM) of theorizing (Allison and Zelikow 1999: 4). The RAM model treats states as unitary rational actors and seeks to explain how those states satisfy their preferences given various external conditions (Ibid: 4-5). But the theory also takes into account the capacity of institutions to constrain actors in the future, producing unintended and unexpected consequences. In so doing, the model is guided by the complementarity of rational choice and historical institutionalism (Katznelson and Weingast 2005; Hall 2010). It rejects, however, the structural determinism expounded by some variants of the latter (Peters et al. 2005: 1278). Instead, the theory places agency at the center of the analysis, thereby infusing historical institutionalism with the micro-foundations necessary for falsifiable hypotheses of institutional change and creation. This section will proceed by discussing, in order: scope conditions, behavioral assumptions, hypotheses and the strategy for empirical testing.

The intuition of the theory is as follows. Coalitions of states create MDBs because they are dissatisfied with the institutional status quo. In response to their dissatisfaction, these states create new MDBs whose distribution and procedure purposefully differ from that status quo. Doing so, however, is expensive, because MDBs are resourcedependent institutions. Eventually, coalitions that lack sufficient resources and/or credit to go it alone will begrudgingly accept the assistance of outside states, ceding partial control of the organization in the process. They do so because they are loss-averse, and thus are willing to take significant risks in order to avoid the certain loss of their new

\footnotetext{
${ }^{3}$ Fawcett and Downs (1986: 6): "[Explanatory] theories move beyond [relational statements and descriptive theory] to the prediction of precise [causative] relationships between dimensions or characteristics of a phenomenon or differences between groups."
} 
countervailing MDB. Coalitions are aware that they are taking a risk, but they are unable to fully anticipate the future consequences of this decision because their rationality is bounded. Subsequently, the providers of the institution's capital exert their leverage over time to force unexpected changes to the institution that directly contradict the original intensions of the founding coalition. This reversion back to the status quo model will engender newfound dissatisfaction, leading states to create yet another countervailing MDB in response. This cyclical pattern of dissatisfactioncreation-reversion-dissatisfaction - creation drives, I posit, the proliferation of MDBs.

\subsection{Scope condition: Countervailing creation}

This model contends to apply to instances of countervailing creation. Countervailing creation is defined as the creation of a new institution by a coalition of actors that have distributional and procedural dissatisfaction with the institutional status quo. ${ }^{4}$ Procedural dissatisfaction is defined as dissatisfaction with the features and practices of the existing institution. This is very similar to what Morse and Keohane (2014: 388) refer to as dissatisfaction with 'rules and institutionalized practices.' Distributional dissatisfaction is defined as dissatisfaction with the distribution of lending dollars in relation to another group of actors and/or for a particular functional purpose. This type of dissatisfaction is more specific to 'pooling' institutions with authority to distribute resources to members (Abbott and Snidal 1998: 13). The 'institutional status quo' refers to the existing institution(s) designed to address the same functional problem(s).

Scope conditions narrow the universe of cases to which theoretical statements contend to be applicable. If these conditions are too narrow, they run the risk of reducing a theory's falsifiability (Harris 1997: 125). This is not the case here. The scope condition of countervailing creation merely provides an anchor for the starting point of the hypotheses. It frames, in other words, the empirical puzzle to be described: the repetitive creation of countervailing alternatives to solve the same functional problems. Section 3.1 provides details on this study's case selection strategy given this scope condition.

\subsection{Behavioral assumptions: Loss aversion and bounded rationality}

The model assumes that actors are loss averse. Loss aversion derives from Prospect Theory (Kahneman and Tversky 1979: 279), the leading behavioral alternative to traditional economic models of rational choice. It assumes that actors compare gains and losses against a status quo reference point. Each has diminishing marginal returns, but losses diminish at a faster rate than gains (Ibid: 279). This implies that losses hurt more than gains satisfy. Further, Prospect Theory anticipates that loss aversion will lead actors to take significant risks in order to avoid those losses. This is particularly true when the loss is perceived as certain rather than probabilistic (Ibid: 265). In fact, the desire to avoid certain loss is so strong that actors may take gambles with a probability of even greater loss (Levy 2013: 314). This is due to the

\footnotetext{
${ }^{4}$ This separation is inspired by social psychologists' distinction between distributional and procedural justice (Thibaut and Walker 1975; Tajfel 1981; Lind and Tyler 1988; De Cremer and Tyler 2005).
} 
'endowment effect:' we strongly dislike losing what we already have (Thaler 1980; Camerer and Loewenstein 2004). ${ }^{5}$

The assumption of loss aversion implies that founding coalitions of countervailing MDBs will take risks to avoid the demise of their new institution by accepting the capital of outside states. This is risky because outside states will demand institutional concessions (e.g., voting power or procedural changes) in return for their assistance. By accepting these concessions, the founding coalition makes a probabilistic gamble in order to avoid the certain loss of their new MDB. The founding coalition's aversion to loss is driven by political considerations. New countervailing MDBs are highly publicized, and often represent an important domestic political victory for each member of the founding coalition. The AIIB, for example, has been widely interpreted as a symbol of China's ambition to supplant the United States' role in global economic governance (Wildau and Clover 2015). Further, these institutions are, by definition, expressions of independence and regional solidarity. Therefore, the loss of a new countervailing MDB because of financing concerns would be highly embarrassing, and likely carry political consequences for the founding members' representatives.

Second, it is assumed that actors have bounded rationality. In other words, actors are self-interested and behave instrumentally, but cannot know all possible alternatives (Simon 1997: 291). In game theory terminology, they are unable to envision the various 'nodes' of a decision-making tree (Jupille et al. 2013: 7). This uncertainty about the future leads actors to 'satisfy' their preferences, often accepting 'good enough' outcomes that are not Pareto-optimal (Simon 1997: 286). The pertinent implication of this assumption is that founding coalitions cannot fully anticipate the future consequences of their decision to accept outside capital in return for institutional concessions. They are aware that this gamble is risky. But because their rationality is bounded, they cannot fully anticipate the nature of those risks or their likelihood. In other words, actors will risk accepting outside investment to preserve the institution at time $t$, but cannot fully predict the future consequences of this decision in time $t_{1+}$.

\subsection{Hypothesis A: Capital endowment and reversion}

The first hypothesis posits that there is a causal relationship between the financial position of a founding coalition and the likelihood that their new institution will change over time in direct contrast to their original intensions. Specifically:

$\mathrm{H} a$ : MDBs created by capital poor coalitions will undergo reversion

Reversion is the dependent variable, and is defined as a type of institutional change in time $t_{1+}$ (indicating the period after the creation of the institution at time $t_{0}$ ), in which the countervailing institution's distribution of lending and procedures change in direct opposition to the original intensions of its founding coalition. Reversion is operationalized as a dummy variable: a countervailing MDB either undergoes reversion (1) or does not (0) within the observation period. Reversion specifically refers to changes in the distribution of loans by sector, the politicization of lending decisions, and loan conditionality. This list does not exhaust all potential types of institutional change. But

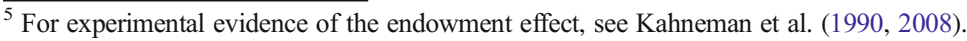


it reflects key distributional and procedural issues that inspire dissatisfied coalitions to create a countervailing alternative to the institutional status quo in the first place (and thus their reversal is, at first glance, particularly puzzling).

Capital Endowment is the independent variable, and refers to the amount of capital available to a coalition at time $t_{-1}$ to fund the creation and operation of a new MDB. This entails both the quantity of capital held by governments and the capacity of those governments to access credit (in domestic and/or international capital markets). Coalitions are coded as either 'capital poor' (0) or 'capital rich' (1). In game theoretic terms, the level of a coalitions' capital endowment is 'given' by nature, and informs their strategic calculations. This binary division is, of course, a simplification. But in the cases observed here classification is straightforward (and empirically supported).

\subsubsection{Intuition and casual mechanism of Hypothesis $A$}

The intuition of Hypothesis A is as follows. MDBs are resource-dependent institutions (Diamond 1957; White 1970; Babb 2009; Humphrey 2016). They rely upon their members' capital contributions and guarantees to borrow at low interest rates and relend that money for development. ${ }^{6}$ Resource needs are particularly acute during the founding of a MDB (Babb 2009). If the founding coalition is capital poor, they lack sufficient capital and/or sovereign credit ratings in order to sufficiently fund the institution. This shortfall will threaten the survival of the new MDB. In such moments, the coalition faces a choice: allow the institution to fail or accept the contributions of outside investors.

Why would capital poor coalitions not fully anticipate this choice? ${ }^{7}$ There are multiple possibilities. First, states may originally over-estimate the commitment of their fellow coalition members to providing financing. Second, states that originally indicate a commitment to provide a certain level of financing may backtrack. Representatives might, for example, face an unexpected level of resistance domestically. Further, external political or economic events may render the original commitment no longer tenable. Third, individual states, upon realizing the extent of their initiallyimplied commitment, may seek to reduce their burden at a later stage by suggesting outside partners. These possibilities are linked by the model's assumption of bounded rationality. States that embark on countervailing creation cannot see into the future, and therefore the necessity of pursuing outside financing is not fully anticipated.

Accepting outside investment is risky, because it necessarily entails the cessation of partial control over the MDB. Outside states will, for example, demand voting power commensurate with their contributions. Further, they may demand key institutional changes, including the creation or alteration of voting constituencies; modifications to organizational rules; and changes to the selection process for executive positions. Thus, like an ailing start-up contemplating venture capital, the coalition must decide between control and survival. It is anticipated that loss-averse actors with bounded rationality will choose the latter. In so doing, the founding coalition undermines their future

\footnotetext{
${ }^{6}$ MDBs often have numerous pools of resources (sometimes referred to as 'soft' or 'hard' windows) that vary in funding structure. These variations can be important for strategic dynamics within MDBs (see, e.g., Humphrey 2016: 101) and will be addressed in the empirical sections below where relevant.

${ }^{7} \mathrm{I}$ am thankful to an anonymous reviewer for bringing attention to this point.
} 
negotiating position by accepting key institutional concessions in return for outside capital. Over time, outside investors will exploit these institutional concessions to effect changes that contradict the founding coalition's original intensions. ${ }^{8}$ Thus the acceptance of capital from outside states is a critical moment in the history of a MDB, in which the decision of the founding coalition in the present leads to undesirable reversion in the future by 'locking in' their negotiating disadvantage. It is, in other words, the mechanism by which the independent variable is purported to affect the dependent variable.

This hypothesized causal mechanism raises an important question: why would the founding coalition not fully anticipate undesirable reversion in response to their

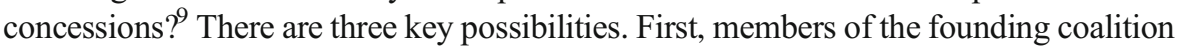
may anticipate reversion but overestimate their capacity to resist. Second, members of the founding coalition may underestimate the manner of, and extent to which, outside investors will seek to exploit their influence. Third, outside investors may purposefully mask or downplay their intensions to do so in the future. These possibilities, which are not mutually exclusive, are linked by the model's behavioral assumptions of loss aversion and bounded rationality. The argument is not that the founding coalition is naïve. To the contrary, they are aware that accepting institutional concessions in return for outside capital is a risk. But because they are loss averse, they prefer probabilistic risk in the future to certain loss in the present. And, because their rationality is bounded, they cannot fully predict the future consequences of this decision.

\subsection{Hypothesis B: Reversion and countervailing creation}

Hypothesis B anticipates that reversion will inspire actors to create yet another countervailing MDB:

\section{$\mathrm{H} b$ : Reversion will lead to countervailing creation}

Where Reversion is a binary independent variable, and countervailing creation is the dependent variable (coded 1 if 'yes' and 0 if 'no'). The internal consistency of the model derives from actors' bounded rationality. Because they were unable to see into the future, the extent and nature of reversion is not fully anticipated. This leads to disappointment and frustration, and members of the founding coalition become, once again, dissatisfied with the institutional status quo.

\subsubsection{Intuition and causal mechanism of Hypothesis $B$}

Reversion is a gradual process. Outside states are expected to exploit institutional concessions slowly over time through a series of individual actions, the cumulative effect of which is gradual institutional change (Mahoney and Thelen 2010). Consistent with Jupille et al.'s (2013) framework, dissatisfied founding coalitions are expected to resist undesirable changes or attempt to introduce favorable changes of their own

\footnotetext{
${ }^{8}$ On this possibility in dynamic bargaining games, see Gärling et al. (1997) and Silvia (2011).

${ }^{9}$ I am thankful to two anonymous reviewers for bringing attention to this point, and to one anonymous viewer in particular for offering one of the possibilities listed in this paragraph.
} 
before embarking upon the arduous process of creating an alternative. The model anticipates, however, that the institutional concessions accepted in return for outside capital in the past will undermine the capacity of the founding coalition to do so in the future.

In order to systematically theorize (and test) this link in the causal chain, we can establish the conditions under which we expect resistance to reversion to be more or less likely. ${ }^{10}$ Specifically, I anticipate that the capacity of the founding coalition to resist reversion in time $t_{1+}$ will decline in proportion to the number of institutional concessions (Table 1) accepted in time $t_{-1}$. In other words, each additional institutional concession accepted in the past further undermines the founding coalition's negotiating power in the future. Table 1 outlines five types of institutional concessions and explains their anticipated strategic impact. I refrain from strictly defining each type of institutional concession, because the specific details (e.g., the proportion of voting power sacrificed or specific procedural change) are expected to vary by case. In order to test this proposition, the case studies below will identify the number of institutional concessions accepted and analyze their future impact.

This article does not seek to systematically theorize the timing of countervailing creation (i.e., when 'enough is enough'). It preliminarily anticipates, however, that 'exogenous shocks' that exert intense pressure upon the institution will be the catalyst for the coalition of actors to translate long-standing dissatisfaction into countervailing creation (consistent with Jupille et al. 2013: 211-12). One potential example is a severe financial crisis that leads a MDB to divert its resources on short-notice and/or fail to satisfactorily support member states. The case studies examined below will seek to evaluate if such exogenous shocks are present in each case.

\section{Empirical strategy}

To evaluate the theoretical model, this article undertakes a structured-focus comparison of three cases: the Asian Development Bank (ADB), Inter-American Development Bank (IADB) and Islamic Development Bank (IsDB). Process tracing will be employed to validate the intuition and mechanisms underlying the hypothesized covariation between the independent and dependent variables, employing a wealth of original data collected by the author.

\subsection{Case selection and observation periods}

Arguments that contend complex causal relationships occur over lengthy time periods face unique challenges of case selection (Bennett and Elman 2006). The argument presented here contends that the proliferation of MDBs is best explained through a series of interconnected causal mechanisms occurring over time. Further, the phenomenon of interest is characterized by the repetitive creation of countervailing MDBs designed to focus on specific geographic regions. In light of these factors and the relatively small number of potential cases, this study requires a purposive (i.e., nonrandom), qualitative selection procedure (Gerring 2008: 645).

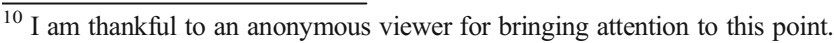


Table 1 Types of institutional concessions and anticipated strategic impacts

\begin{tabular}{cc}
$\begin{array}{l}\text { Type of Institutional } \\
\text { Concession in } t_{-1}\end{array}$ & Anticipated Strategic Impact in $t_{1+}$ \\
\hline Voting Power & $\begin{array}{c}\text { The founding coalition will lack sufficient collective voting power to resist } \\
\text { reversion. Conversely, outside states will have sufficient votes to veto } \\
\text { counter-measures proposed by the founding coalition (see Tsebelis 2002). }\end{array}$ \\
Voting Thresholds & $\begin{array}{c}\text { The level of consensus necessary to approve individual projects or changes to } \\
\text { institutional rules will favor outside states. This may, for example, entail } \\
\text { high thresholds for rule changes designed to preserve outside states' } \\
\text { strategic advantages. } \\
\text { Placement of the founding members in separate voting constituencies, } \\
\text { sometimes headed by Executive Directors from non-regional states, will } \\
\text { undermine the capacity of the coalition to act in concert. }\end{array}$ \\
Procedural Rules/Corporate & $\begin{array}{c}\text { Certain procedural rules and/or governance arrangements, such as the process } \\
\text { for loan approval, will be designed in a manner that provides outside states } \\
\text { Governance }\end{array}$ \\
with opportunities to block projects and/or institutional changes they deem \\
undesirable. \\
The process for selecting executive positions will give preference to nationals \\
of outside states.
\end{tabular}

\footnotetext{
${ }^{a}$ The nationality of the Executive Director representing voting constituencies usually (but not always) rotates among members

${ }^{\mathrm{b}}$ The desire to influence this process can also be usefully conceptualized a method by which the principal (outside state) seeks to controls their agent, the MDB, through control of staffing (see Parízek 2017)
}

First, it was necessary to eliminate from consideration any MDBs that do not constitute instances of countervailing creation. One clear example is the Londonbased European Bank for Reconstruction and Development (EBRD). The EBRD was created in 1991 with an explicit goal of helping Central and Eastern European states transition from communism to market-oriented economies (Culpeper 1997: 32). It was a donor-driven initiative rather than an attempt to establish a countervailing alternative to a dissatisfactory institutional status quo. Second, the selected MDBs need to have been created early enough to observe whether (a) they underwent reversion and (b) this led to the creation of yet another countervailing MDB by members of the same coalition. This led naturally to the first set of regional MDBs established in response to the World Bank: the IADB, African Development Bank (AfDB), ADB and IsDB. Preliminary research indicates that this group includes three instances of capital poor founding coalitions (IADB, AfDB, ADB) and one instance of a capital rich founding coalition (IsDB).

This final set provides the opportunity to employ what Gerring (2008: 650) refers to as a 'diverse-case' method. This method requires the selection of two or more cases intended to represent the full range of values characterizing the independent and dependent variables or some particular relationship between the two. In so doing, the diverse-case method incorporates elements of the 'most similar' and 'most different' approaches to case selection (Ibid: Footnote 3). Here there are two sub-groups of cases based on capital endowment: capital poor and capital rich. For capital poor coalitions, the model expects to observe reversion and, subsequently, the creation of yet another countervailing alternative. For capital rich coalitions, neither reversion nor repetitive 
creation is expected. In order to ensure that the latter sub-group is represented, it is necessary to select the IsDB. Analogous to the 'most similar' method, the IsDB shares a common dissatisfactory status quo with the IADB, ADB and AfDB (the World Bank) but differs on the independent variable (capital endowment).

Among the three members of the capital poor sub-group, the ADB and IADB are selected randomly. Comparing these institutions enjoys certain advantages of the 'most different' approach. The ADB and IADB were created on two different continents with distinct histories, political dynamics and economic circumstances. They share, however, the same classification (capital poor) and, therefore, are expected to exhibit similar patterns despite variation in unobserved factors. By selecting cases that vary on both the independent and dependent variables, this study can pursue 'confirming' rather than merely 'exploratory' evidence (Seawright and Gerring 2008). The observation period for each case runs from the beginning of the negotiations of each bank's founding to the present: ADB (1963-2017); IADB (1948-2017); IsDB (1970-2017).

\subsection{Measurement of Hypothesis A}

Measuring capital endowment (the independent variable) is methodologically difficult, but in the cases observed here classification is straightforward. ${ }^{11}$ The founding coalitions of the ADB and IADB emerged from World War II with substantial investment needs and severely underdeveloped capital markets, and therefore are coded ' 0 ' for capital poor. ${ }^{12}$ In contrast, members of the Organization of Arab Petroleum Exporting Countries (OAPEC) founded the IsDB shortly after the nationalization of oil production in the 1970s. Acquiring control over their oil sources provided OAPEC states with remarkable wealth, and therefore the founding coalition is coded ' 1 ' for capital rich.

Reversion (the dependent variable) is measured using three institutional characteristics: distribution of loans by sector; politicization of loans; and policies of loan conditionality. Because the observation period for each bank is lengthy, it is important to ensure that any aspect of reversion does not occur because of changes in the preferences of the founding coalition (producing false positives). In order to avoid this, two conditions are added to reversion. First, reversion must directly contradict the original intensions of the founding coalition. This requires establishing these intensions in each case. Second, reversion must be resisted by the founding coalition. Thus, in order to be coded ' 1 ' for reversion, a MDB must undergo changes in each category that (a) directly contradicts the original intensions of the founding coalition; and (b) are resisted by that coalition. These requirements provide a number of avenues for falsifiability.

\subsection{Measurement of Hypothesis B}

The measurement of reversion (now the independent variable) is provided by its measurement under Hypothesis A. The dependent variable of countervailing

\footnotetext{
${ }^{11}$ Future applications of the model may require a more precise measurement method.

12 On the economic needs of the ADB's founders, see: Zinkin (1954: 11); Wightman (1963: 101); Abbas (1956: 124-26); Kirby (1950: 16). On the IADB's founders, see: Bulmer-Thomas (2014: 383); Prebisch (1950: 5); Pan-American Union (1949: 9).
} 
creation in time $t_{1+}$ is measured by observing the creation of yet another countervailing institution by at least a sub-set (three or more members) of the founding coalition. This new countervailing institution must be inspired by distributional and procedural dissatisfaction with the reversion of the original countervailing institution. In response to this dissatisfaction, this new coalition must establish a new MDB whose distribution and procedures directly contradict that reversion. If reversion does not lead to countervailing creation within the observation period, Hypothesis $\mathrm{B}$ is falsified. If countervailing creation occurs vis-à-vis a MDB that has not undergone reversion, this, too, is disconfirming evidence.

\subsection{The data}

The author conducted 48 interviews at the ADB in Manila, Philippines, the IADB and World Bank in Washington, D.C., and the EBRD in London, in addition to various embassies, chambers of commerce and think tanks. Additional telephone interviews were conducted with individuals at the IsDB, Nordic Investment Bank and U.S. Treasury Department. Archival documents were consulted at the World Bank Archives, the Library of the Organization of American States (Washington, D.C.) and the ADB Archives. The United Nations Economic and Social Commission for Asia and the Pacific (ESCAP) in Bangkok provided additional archival documents via email, and the ADB scanned and delivered to the author 37 documents summarizing the Annual Meetings of the Board of Governors from 1966 to 2003. In addition, quantitative data on lending and voting rights is obtained from the annual reports of each MDB. The empirical results are summarized below (Table 2).

\section{The Asian Development Bank}

On October 24th, 2014, a Chinese-led coalition of Asian states agreed to create the Asian Infrastructure Investment Bank (AIIB). The AIIB, as its name suggests, will focus on much needed infrastructure financing. An often-cited and corroborated study

Table 2 Summary of empirical results

\begin{tabular}{|c|c|c|c|c|c|c|}
\hline Bank & $\begin{array}{l}\text { Capital } \\
\text { Endowment }\end{array}$ & $\begin{array}{l}\text { Accepted } \\
\text { Outside } \\
\text { Capital }\end{array}$ & $\begin{array}{l}\text { Hypothesis A } \\
\Delta \text { Lending by } \\
\text { Sector }\end{array}$ & $\begin{array}{l}\Delta \text { Politicization of } \\
\text { Lending }\end{array}$ & $\Delta$ Conditionality & $\begin{array}{l}\text { Hypothesis B } \\
\text { Countervailing } \\
\text { Creation }\end{array}$ \\
\hline $\mathrm{ADB}$ & 0 & Yes & Yes & Yes & Yes & Yes AIIB \\
\hline IADB & 0 & Yes & Yes & Yes & Yes & Yes B. Sur, CAF \\
\hline IsDB & 1 & No & No & No & No & No N/A \\
\hline
\end{tabular}

$\Delta$ refers to reversion. 'B. Sur' refers to BancoSur 
by the ADB (2009a) estimates that Asia will require approximately $\$ 8$ trillion in infrastructure investment between 2010 and 2020. ${ }^{13}$ The new Bank will also address its founding coalition's concern with the slow, bureaucratic loan approval process of existing institutions, and the burdensome social and environmental conditions attached to those loans. ${ }^{14}$ At first glance, the necessity of establishing the AIIB is puzzling. These states are already members of an institution dedicated to the development of Asia, one whose commitment to infrastructure was once so strong that it was colloquially referred to as Asian Dams and Bridges (ADB). And, indeed, the ADB was first conceived as a countervailing alternative to the World Bank, in which the needs and policy preferences of Asian countries would be prioritized. This begs the question: what happened to the ADB, and why is the AIIB necessary?

\subsection{Dissatisfaction with the World Bank}

By the end of the 1960s, Asian members were dissatisfied with the distribution of the World Bank's lending and the procedures of the institution. Regarding distribution, Asian states were dissatisfied with their relative share of funds. Only one-third of funding from the World Bank's original institution, the International Bank for Reconstruction and Development (IBRD), had gone to Asia from 1945 to 1966, despite that the region held half the world's population (Magill 1996: 891). As the ADB's first president Takeshi Watanabe (1973: 1) recorded in his memoir, "We felt that the requirements of Asian development were too large to be met solely by the World Bank, whose activities in Asia-except in India and Pakistan-were far from adequate." Asian members were also dissatisfied with the distribution of the World Bank's loans by sector. These states desired financing for agriculture, infrastructure and agro-industry. ${ }^{15}$ But on the eve of the ADB's founding in 1966, only $34.5 \%$ of total World Bank lending dollars went to infrastructure financing. Equally disappointing was the decline in the World Bank's agriculture lending (never representing more than $10 \%$ of the Bank's portfolio from 1953 to 1966), less than a third of which went to the Asian region. ${ }^{16}$

Asian states were also dissatisfied with the procedures (i.e., features and practices) of the World Bank. From the outset, the U.S. and its European allies dominated the IBRD, which was headquartered just a stone's throw away from the White House. By 1966, the U.S. held approximately $26 \%$ voting power in the World Bank, compared to $13.5 \%$ for the whole of Asia (IBRD Annual Report 1966: Appendix C). Further, there is an informal (but consistently obeyed) rule that the World Bank's President is always American. Asian states' lack of voice within the institution rendered them vulnerable to the politicization of lending, often driven by the interests of the Bank's largest shareholders: the U.S., U.K., and France (Kapur et al. 1997: 102). In 1966, for example, Nepal desired financing for the construction of an airstrip. But in a personal letter, thenPresident George Woods expressed reservations:

\footnotetext{
${ }^{13}$ Also see Andrés et al. (2014).

${ }^{14}$ Interviews \#23, 33, 37, 38, 39.

${ }^{15}$ ECAFE (1966: 32-51) lists the public statements of Asian countries urging that the ADB fund much-need agriculture and infrastructure projects, which were thus far insufficiently financed by the IBRD.

${ }^{16}$ Calculated based on data obtained from World Bank Annual Reports, 1953-1966.
} 
I don't think it [is] advisable for the Bank to be prominently identified with the financing of such a project-located as it would be between the two largest centers of population in the world [India and China], whose relations are not friendly (April 22 nd, 1966 : World Bank Archives File \#1769735).

Nepal's capacity to contest this decision would have been next to impossible given its voting power $(0.14 \%)$ and placement in a voting constituency (IBRD Annual Report 1966). Nepal would later express its frustration during the negotiations of the ADB (ECAFE 1966: 97): "unless the smaller countries have an effective voice in the workings of the proposed Bank [its] objectives will possibly not be adequately fulfilled." Further, Asian states were dissatisfied with the Bank's increasingly interventionist approach, including invasive ex post supervision and conditionality concerning monetary and fiscal policies (Kapur et al. 1997: 78, 80, 81, 87). In 1965, for example, India begrudgingly adopted an austerity package in return for financing that included credit controls and import liberalization (Chaudhry et al. 2004: 62). The inability of these states to change the IBRD left them with only one option: create a countervailing alternative.

\subsection{Countervailing creation: The Asian Development Bank}

The original conception of the ADB can be traced to 1963, when the Asian members of the United Nations Economic Commission for Asia and the Far East (ECAFE) discussed the creation of a regional Asian bank. These early meetings purposefully restricted attendance for Asian states: "[it was] the only international conferences sponsored by ECAFE... with the mandate to exclude ECAFE's non-Asian members" (Huang 1975: 27). The ADB was originally conceived to address its founding coalition's dissatisfaction with the distribution and procedures of the World Bank. Regarding distribution, its founding coalition enshrined as one of its goals: "The financing especially for those projects...which at present are not financed or not adequately financed through existing sources or agencies" (ECAFE 1965: 1). Specifically, the founding coalition emphasized that the ADB should focus on agriculture, infrastructure and agro-industrial production. Ceylon, China, India, Nepal, Pakistan and the Philippines, for example, directly cited the need for agriculture at a 1964 meeting of ECAFE, and significant attention was also paid to investments in transportation (ECAFE 1964: $57,61,66,67,79,89,92,100)$.

The founding coalition also anticipated that the ADB would adopt features and practices that directly contradicted the World Bank, thereby addressing their procedural dissatisfaction. As the Cambodian delegate summarized: “...the doctrine which has been put forward [by the World Bank] is in contradiction with its practice and concrete reality... the time of [the ADB's] establishment must be an occasion to rethink and reexamine the principles..." (ECAFE 1966: 21). ${ }^{17}$ Those new principles would include four key changes. First, voting based on 'one nation-one vote' representation in contrast to the IBRD's 'one dollar-one vote' formula (ECAFE 1964: 21). Second, the Board of Directors would be at least majority Asian, and small nations opposed grouping

\footnotetext{
${ }^{17}$ Afghanistan also remarked: “. . a bank operated in accordance with the existing policies of IBRD would not meet the needs of the region." ECAFE (1964: 43).
} 
members into constituencies (Ibid: 21, 26, 28, 90, 96, 97, 99). Third, members anticipated that the ADB, unlike the IBRD, would select its President based on merit rather than on nationality or voting power (Ibid: 23, 25, 26, 31, 99). And, finally, the ADB's loans were not to entail invasive political or economic conditions (Ibid: 88-89, 99; Yasutomo 1993: 309). The ADB was, in sum, a prime example of countervailing creation.

\subsection{Accepting outside capital}

"Initially," writes the ADB's first President Takeshi Watanabe in his memoir (1973: 6), "the view was expressed that the membership should be limited to Asian countries since this bank was an Asian institution." And, indeed, the ADB was conceived in the spirit of Asian independence, anti-colonialism and regional solidarity. There was, however, one problem: how would it be paid for? Japan would be the first to suggest that the bank seek outside financing, a "proposition met with considerable resistance" (Ibid: 7). ${ }^{18}$ At one point U Nyun, President of ECAFE, threatened to go it alone without Japan if non-regional members would not agree to the original principles of the bank (Wilson 1987: 8). As the Ceylonese delegation summarized, “...for historical reasons, the countries of Asia may be fearful that this Bank, the fruit of their strenuous efforts, will be dominated by great powers..." (ECAFE 1966: 90).

The theoretical model would anticipate that, despite these fears, loss-averse actors would rather take risks to preserve the institution than lose the fruit of their strenuous efforts altogether. And, indeed, the founding coalition succumbed. By the end of the negotiations non-regional states held approximately $48 \%$ voting power, and the United States became joint-top shareholder with Japan (ADB 1967). The coalition also accepted 'one dollar-one vote' representation; large voting constituencies; a separate Executive Director for the U.S.; and an informal rule that the President would always be Japanese (Orr 1990). Further, they adopted a constitutional provision stating that no member can have its capital subscription (and thus its voting power) reduced involuntarily (ADB 1966: Article 5.2). Finally, any alterations of constituencies require a twothirds supermajority vote, rendering changes unlikely (Ibid: Article 30, B.ii). Here we see all five types of the institutional concessions outlined in Table 1: Voting Power; Voting Thresholds; Voting Constituencies; Procedural Rules/Corporate Governance; and Executive Positions. And, as the model anticipates, these concessions 'locked-in' the negotiating disadvantages of the founding coalition, reducing their capacity to resist undesirable reversion in the future.

\footnotetext{
${ }^{18}$ It is unsurprising that Japan, the wealthiest country in the region, was the first to suggest that the founding coalition seek outside financing. In the course of the negotiations, Japan realized that it would need to provide a large share of the initial capital. As White (1970, p. 41) writes, “...Japan was initially reluctant to become unequivocally committed, lest it should find itself bearing a disproportionate financial burden." This realization exemplifies why founding coalitions of countervailing MDBs may not fully anticipate the need to pursue outside financing at the beginning of the negotiations. Specifically, it is an example of a state that, upon realizing the extent of its initially-implied commitment, seeks to reduce its financing burden at a later stage by suggesting outside partners (see Section 2.3.1).
} 


\subsection{Reversion in lending by sector}

The ADB was originally conceived to focus on agriculture, infrastructure and agroindustry - areas in which the World Bank was found to be unsatisfactory. The ADB's distribution of loans by sector has, however, changed dramatically over time. Since the late 1980s the ADB's portfolio has diversified considerably. From 2014 to 2016 over $40 \%$ of lending, on average, went to sectors not originally considered a priority by the founding coalition: Education; Finance; Health/Social Protection; Public Sector Management; and Water Supply/Other Municipal Services. In contrast, Agriculture and Industry have declined from a three-year rolling average of approximately $36 \%$ in 1968-1970 to $10 \%$ in 2014-2016. ${ }^{19}$ As Fig. 2 summarizes, lending for the founding coalition's priority areas have collectively declined as a percentage of total over time, primarily driven by increased diversification. These trends closely match equivalent changes in distribution by sector at the World Bank, indicative of the preferences of certain outside states with significant influence over both institutions. ${ }^{20}$

This reversion directly contradicts the original intensions of the founding coalition. Japan has often characterized the ADB as a specialized 'family doctor,' able to cure the region's specific economic maladies (Watanabe 1973; ADB 2009b). But regional members (e.g., India and China) have recently lamented that this is no longer the case. Rather, they expressed in an internal ADB questionnaire that "we were trying to become a large hospital and pretending to be something we were not supposed to be" (ADB 2009b: 148, emphasis added).

This was corroborated by interviewees; one ADB economist noted, "China's fed up with the ADB trying to be a full-service bank, they want it to be leaner and meaner... they don't care about these [soft] development issues" (Interview \#39). Regional states protested these declines in agriculture and industry investments in the 1990s (ADB 1990: 32). But any attempts to resist reversion in loan distribution in time $t_{1+}$ were undermined by corporate governance concessions made in time $t_{-1}$. The low voting power and governance disadvantages of regional members reduced their capacity to reject undesirable changes often demanded by non-regional states during periods of capital replenishment. In the 1990s, for example, the U.S. Treasury Department was able to force the ADB to (informally) commit to devoting an astounding $40 \%$ of its resources to social or environmental sectors (Babb 2009: 167). As one employee morosely observes: "Every time...donor countries have to give more money to the ADB, they always ask what they are going to get in exchange" (ADB 2009b: 141).

\subsection{Reversion in the politicization of lending}

Institutional concessions also undermined the coalition's capacity to reduce the politicization of lending. In 1989, for example, the ADB suspended loans to China in response to the Tiananmen Protests, prompting China to object: "This [cessation of lending]...contravenes the spirit of the Bank's Charter and impairs the integrity of the

\footnotetext{
${ }^{19}$ Calculations performed by the author based on data collected from ADB Annual Reports, 1966-2016.

${ }^{20}$ The proportion of lending directed toward agriculture, industry (non-energy) and infrastructure at the World Bank has declined from approximately $54 \%$ in 1976 to $28 \%$ in 2016 . The proportion of lending for health, education, finance and public-sector management, in contrast, has risen from approximately $5 \%$ to $45 \%$ in the same period. Calculations performed based on World Bank Annual Reports 1976-2016.
} 


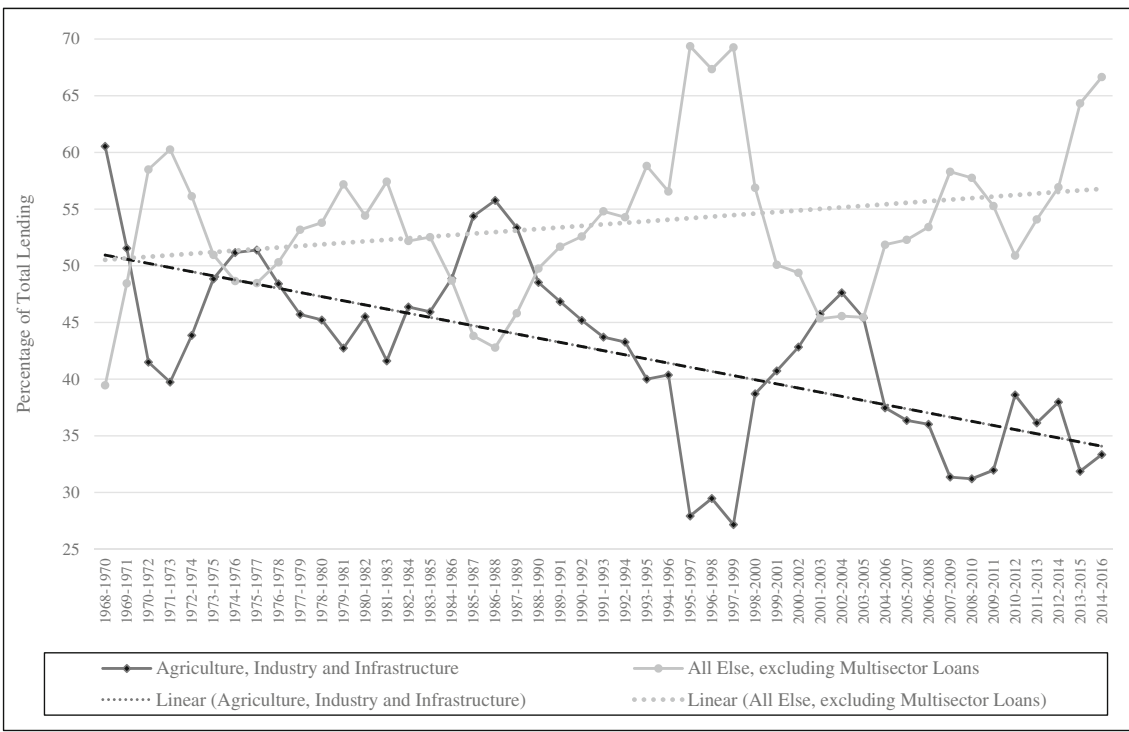

Data collected from ADB Annual Reports, 1966-2016. The significant spike between 1995-1997 and 1997-1999 reflects an abnormally large increase in financial assistance to member states in response to the 1997 Asian financial crisis.

Fig. 2 ADB lending by sector, 1968-2016 (three-year rolling averages)

Bank" (ADB 1991: 56, emphasis added). Another suspension of assistance to Afghanistan in response to its 1990 civil war prompted further anger:

It is most surprising and annoying that the Bank...should withhold and suspend its lending facilities to one of its most needy, loyal and least developed landlocked members in the continent of Asia. This attitude of the Bank...is not only contrary to its own Charter but also a regrettable misstep into the quagmire of anachronistic obstructionist policies based on noneconomic factors... [this is] not acceptable and beyond description... (ADB 1990: 30, emphasis added).

Suspensions in response to political considerations directly contradicted a central desire of the founding coalition. But the capacity of Asian states to resist was undermined by institutional concessions accepted in return for outside capital in 1966.

\subsection{Reversion in conditionality}

Finally, the ADB experienced a reversion in its policies toward conditionality, driven by the bank's largest non-regional shareholders. The U.S. and European states promoted the 'Washington Consensus' in the 1980s, a set of policy prescriptions emphasizing market liberalization, democracy and fiscal conservatism (U.S. Treasury Department 1982; Babb 2009: Ch. 4). Numerous Asian states fiercely protested (to little avail) the direct application of the Washington Consensus to ADB lending. ${ }^{21}$ Further, current

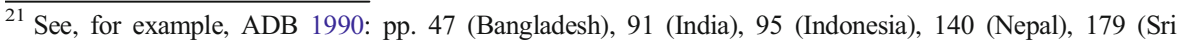
Lanka); ADB (1991), pp. 102 (Malaysia), 117 (Nepal), 132 (Papua New Guinea).
} 
ADB representatives expressed frustrations via interview with new, primarily Western preferences for environmental and social loan conditions. For example, numerous nonregional countries are averse to coal-powered energy. ${ }^{22}$ But as the representative of one recipient state noted: "it's more realistic for our countries...it's cheap...it's efficient" (Interviews \#37 and 38). A similar attitude was expressed toward 'gender impact' targets: "[for developing members] gender is maybe a concern but it's not our priority....if you limit financing to only females, that's unrealistic [for us]" (Ibid). The founding coalition's corporate governance disadvantages have, however, undermined their capacity to resist the imposition of conditionality. These changes, in addition to the ADB's reversion in distribution by sector and the politicization of loans, have driven the founding coalition to establish yet another countervailing alternative: the AIIB.

\subsection{Countervailing creation: The AIIB}

As the model anticipates, dissatisfied members of the founding coalition attempted to change the ADB before creating the AIIB. In 1991, for example, Sri Lanka lamented that small states were not represented on the ADB's Board of Directors, and urged the Bank (unsuccessfully) to alter the situation (ADB 1991: 145). No member has been more vocal in its attempts to increase Asian voting power, however, than China. ${ }^{23}$ Former U.S. Executive Director Cinnamon Dornsife confirmed via interview: "They were frequently calling for special capital increases... [China] would love to increase its share size and therefore its voice and vote." Another Executive Director corroborates: "China and India have always wanted influence...it's a frustration with Western dominance in these institutions [ADB and World Bank]" (Interview \#32). The distribution of voting power is, however, a zero-sum game; as Dornsife summarizes, "For one to increase, the rest have to decrease." Thus, the institutional concessions accepted in time $t_{-1}$ inhibited the founding coalition's negotiating power in time $t_{1+}$.

With satisfactory change not possible, dissatisfied members of the founding coalition began discussing an alternative as early as 1991 (Cho and Katz 2001). The new bank would address distributional concerns by focusing on much-needed infrastructure financing insufficiently covered by the ADB and World Bank (Izotov 2014). Further, it would address procedural concerns by ensuring significant voting power for Asian states (Katz 1996: 133). Interviewees representing Asian states anticipate that the AIIB will happily fund coal-power projects, and not attach what they perceive to be burdensome conditions (Interviews \#37 and 38). The AIIB is, in other words, a prime example of countervailing creation. It was rendered necessary by the incapability of the ADB's founding coalition to resist undesirable reversion in time $t_{1+}$ due to institutional concessions accepted at time $t_{-1}$.

What explains the timing of the AIIB? Evidence suggests that the 2008 financial crisis was key. As noted above, regional states have long been dissatisfied with the ADB's level of infrastructure financing. Sri Lanka summarized this dissatisfaction

\footnotetext{
${ }^{22}$ The U.S., for example, is required by (domestic) law to reject any proposal that does not submit a sustainability report 120 days before it is submitted to the Board (Sanford and Fletcher 1998). And, as former U.S. Executive Director Cinnamon Dornsife noted via interview, "As this was required by law, we were sticklers about enforcing this rule." (Interview \#5).

${ }^{23}$ For examples of Chinese dissatisfaction, see ADB (2014); ADB (2013); ADB (2012); ADB (2011); ADB (2009c); ADB (2007); ADB (2006).
} 
during the 2014 meeting of the ADB's Board of Governors: “...we welcome the initiative to create the Asian Infrastructure Investment Bank...We have been talking about such funding for a long time" (ADB 2014). The financial crisis accentuated this gap; general financing for infrastructure declined sharply and has yet to return to pre2008 levels (ADB 2016; He 2016). Further, the crisis raised serious questions about the capacity of the ADB and World Bank to satisfy Asia's growing infrastructure needs (Mishra 2016: 168). MDBs were forced to commit extraordinary resources to financial assistance, further reducing the likelihood of increased infrastructure financing. Chinese state-owned news agency Xinhua (2016) summarized the country's frustration in an article on the AIIB: "The current international economic and financial system, represented by the U.S. dominated-World Bank [sic]...has shown its defects especially in the wake of the 2008 global financial crisis." The crisis was, in other words, an exogenous shock. Consistent with this article's preliminary anticipation, it was the spark that translated long-standing procedural and distributional dissatisfaction into countervailing creation.

\section{The Inter-American Development Bank}

In 2009 a coalition of Latin American states announced the establishment of the Bank of the South (BancoSur). The BancoSur will become the seventh MDB in the region, and was created by its founding coalition to serve as a countervailing alternative to existing multilateral institutions. Regarding distribution, it plans to concentrate financing toward its South American members, and will avoid projects that entail intrusive 'modernization' of domestic institutions. Procedurally, it will exclude non-regional members and institute one nation-one vote representation, thereby enhancing the voice of Latin American borrowers. Like the AIIB vis-à-vis the ADB, the creation of BancoSur is, at first glance, puzzling. These states are already members of the InterAmerican Development Bank (IADB), established in 1959 as a countervailing alternative to the IBRD. Thus, like the ADB vis-à-vis the AIIB, we are faced with two interrelated questions: what happened to the IADB, and why is the BancoSur necessary?

\subsection{Dissatisfaction with the World Bank}

Latin American states had high expectations for the IBRD. The region believed that it deserved substantial capital investment in return for its assistance to the Western Allies during World War II (Diaz-Bonilla and Campo 2010: 44). Latin American states subsidized the war effort by selling primary commodities at an artificially low rate. In 2016 USD, these lost profits entailed, in effect, a \$40 billion non-interest-bearing loan to the United States with no collection on principle (Rabe 1988: 16-17). ${ }^{24}$ By selling at controlled prices, approximately half of Costa Rica's coffee crops were depleted. And Chile, subsidizing U.S. imports of copper and nitrates, lost, in 2016 USD, more than $\$ 6$ billion (Ibid: 16).

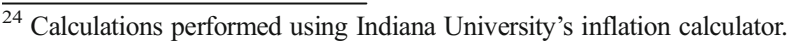


Despite these sacrifices, only $21 \%$ of the World Bank's lending dollars went to the region from 1945 to 1959 (IBRD 1959). Latin American states were also dissatisfied with the distribution of the World Bank's loans by sector, desiring financing for agriculture, industry and social infrastructure (Dell 1972: 20). At a 1949 meeting to discuss the potential creation of an institutional alternative, Mexico summarized the region's distributional (and procedural) dissatisfaction:

The International Bank for Reconstruction and Development is giving preference to reconstruction of the devastated countries, and the economic aid to which it can give to the American Republics for their development has hitherto been insufficient, due perhaps to its limited resources, the origins thereof, and the rules that govern its operations... (Pan-American Union 1949: 4).

Latin American states also became dissatisfied with the IBRD's procedures. In 1959 the region collectively held only $9 \%$ voting power in the World Bank, and every member was grouped into a voting constituency (IBRD 1959: 38). This lack of voice within the institution made it extremely difficult to resist the politicization of loans. Nicaragua, for example, received nine loans from 1945 to 1955 (compared to zero for Guatemala) for assisting the U.S. with the Bay of Pigs invasion (Kapur et al. 1997: 103).

Lack of representation also undermined resistance to the imposition of intrusive lending conditions. Particularly contentious was the Bank's 1951 requirement that Brazil decrease inflation, reduce subsidies, alter its currency value, erase debt, undergo austerity programs and even decrease oil imports in return for continued assistance (Mason and Asher 1973: 660-62). Chilean President Gabriel Gonzalez expressed the region's collective frustration in the same year: "The International Bank does not deserve its pompous title... because it is not inspired by the noble principle of effectively helping under-developed countries..." (New York Times 1951). Like their contemporaries in Asia, Latin American states were unable to change the institution, leaving them with one option: create a bank of their own.

\subsection{Countervailing creation: The Inter-American Development Bank}

In response to the deficiencies of the World Bank, Latin American members began discussing a regional alternative at the United Nations Economic Council for Latin America (ECLA) as early as 1948. Argentine economist Raúl Prebisch led the ECLA from 1950 to 1963, and under his leadership the agency developed a reputation for fierce independence and regional integration (Dosman 2008: Ch. 12). Prebisch (1950) argued that the international financial system was inherently asymmetrical. The Latin American 'periphery' could only ensure their independence from the North American and European 'core' if their economies underwent import-substitution-industrialization (ISI), whereby foreign imports are replaced with domestic production. ISI required, however, substantial capital, and the World Bank's lending to the region was thus far insufficient.

It was in the context of this independent spirit that the IADB was originally conceived. Latin American members of ECLA would form its founding coalition, 
and met in Santiago, Chile in 1955 without the presence of the United States or other non-regional countries to discuss it design and functions. The founding coalition originally anticipated that the IADB would address its distributional and procedural dissatisfaction with the World Bank. Regarding distribution, the IADB would compensate for the IBRD's insufficiencies; as The New York Times reported (1955):

Many Latin-American [sic] Governments feel that they cannot obtain the desired financial support from existing agencies and that a pooling of their resources would prove a more adequate source of funds for economic development.

The IADB would also address the founding coalition's dissatisfaction with the World Bank's distribution of loans by sector, prioritizing agriculture and social infrastructure, i.e., urban development, water, sanitation, health and education (Dell 1972: 20 ). Further, the IADB would, unlike the IBRD, finance projects in local currencies to reduce the cost of repayment (Pan-American Union 1949: 33).

Procedurally, the bank would be "administered with a strong Latin American voice..." (Valdivieso 1959: 3). Regional states would collectively hold a majority of voting power, and a draft charter prevented any one member from holding more than $33.33 \%$ of the votes (Serrano 1959: 1). To further ensure that the IADB would remain a Latin American institution, it was decided that its headquarters should be in the region. Bolivia, Costa Rica, Cuba, El Salvador, Panama and Venezuela originally contended that Caracas would be an appropriate location (Dell 1972: 74). The Bank would also avoid intrusive conditionality. As Brazil stressed in 1960: "The Bank will maintain a proper attitude of non-intervention in the internal politics of the member countries and will respect the fundamental legal institutions" (IADB 1960: 49). And, indeed, this desire was solidified in the IADB's charter (1959: Article VIII, Section 5f), which explicitly states that the Bank will (a) not interfere in the political affairs of its members; and (b) make decisions based on strictly economic considerations. As the negotiations proceeded, however, there was a looming, unresolved issue: funding.

\subsection{Accepting outside capital}

During the early negotiations of the IADB, there was discussion of limiting the membership of the bank to Latin American states. In 1954, for example, the Chilean delegation discussed the possibility of going it alone without the help of non-regional countries (Dell 1972: 9). These thoughts were, however, short-lived. Latin American states simply lacked the capital (and creditworthiness) to fund a new development bank (Pan-American Union 1949: 23). Thus, in line with the model's expectations, the coalition took the risk of accepting outside capital in order to avoid certain loss.

American assistance would not come cheap. Thomas Mann, head of the U.S. negotiating team, was explicit: "Latin Americans like a buck in their pocket and a kick in the ass... They don't think like us. Their thought processes are different. You have to be firm with them." (Dosman 2008: 341). Before proceeding, the U.S. demanded that Prebisch, whom the Central Intelligence Agency labeled subversive, be excluded from the negotiations (Ibid). With Prebisch out of the picture, the U.S. would gain significant concessions. First, the IADB was to be located in Washington, D.C. rather than 
Caracas. Second, the US acquired control of the Executive Vice-President position. The Executive Vice-President controls the powerful Loan Committee that is responsible for reviewing all loan applications before approval (Birdsall 2014: 7). Third, the U.S. attained veto power over the IADB's 'soft' lending window by demanding (a) twothirds majority to approve loans; and (b) an initial shareholding of $42.05 \%$, thereby contradicting the original proposal of a $33.33 \%$ limit for any one member (DeWitt 1977: 24) ${ }^{25}$ Fourth, the U.S. 'locked-in' its representational advantage by installing a remarkable clause in the IADB's charter (1959: Article VII, Section 4b): there can be no capital replenishment or change in capital subscriptions that results in "the member having the largest number of shares below 30 percent of such total voting power." 26

Fifth, the IADB endows each state with the right to subscribe to the same number of shares as they held previous to any negotiation (Ibid). And, finally, only the U.S. (and later Canada) has its own seat on the Board of Executive Directors. At the end of the negotiations, the U.S. held de facto veto power over the quorum required for meetings of the Board of Governors; quorum for meetings of the Executive Directors; increases in the capital stock of the Bank; and amendments to the Articles of Agreement. As one observer noted with considerable understatement, the end product "did not represent as radical a change in policy as many Latin Americans had originally expected" (Wagner 1970: 142). Like the ADB, the IADB's founding coalition accepted all five types of concessions outlined in Table 1. And, also like the ADB, these concessions in time $t_{-1}$ inhibited the capacity of the IADB's founding coalition to resist reversion in time $t_{1+}$.

\subsection{Reversion in lending by sector}

Like the ADB, the IADB's distribution of loans by sector changed dramatically in the late 1980s and 1990s. But unlike the regional members of the ADB, Latin American states were not averse to the diversification of the bank's portfolio or increased lending for 'soft' sectors. Rather, the founding coalition became dissatisfied with the dramatic rise in policy-based lending, labeled 'Reform and Modernization of the State.' This category entails fiscal reform; public expenditure management; public sector reform; decentralization; changes in intergovernmental revenues; subnational and local government reform; public debt management; modernization/administration of justice; reform of the state; management for development results; and e-government. ${ }^{27}$ Lending for this sector began immediately after Ronald Reagan's second term. This trend is roughly matched (albeit with lag) by the World Bank's own increase in policy-based lending, termed 'Public Administration.'

This quantitative change is corroborated by qualitative evidence of an alteration in the IADB's lending strategy. Inspired by free market principles, the Reagan administration (1981-89), backed by the IADB's newly admitted European states, began to advocate for alterations in the domestic political and economic structures of regional members throughout the 1980s. Britain warned that this would entail a significant deviation from the bank as originally conceived (IADB 1985: 64). And, indeed, the

\footnotetext{
${ }^{25}$ Strand (2003: 30), employing the Johnston voting power index, calculates that the U.S. actually has $76 \%$ voting power when one takes into account the organization of constituencies.

${ }^{26}$ Interviewee \#7 confirmed the intensions of this clause; Canada has a similar provision ensuring that it holds $4 \%$ of the vote.

${ }^{27}$ The labels used to describe this sector and sub-categories have varied over time.
} 
proportion of lending for agriculture - a key area of initial focus - dropped from $24 \%$ in 1989 to $8 \%$ in 1990 , and has averaged less than $4 \%$ ever since. $^{28}$

Latin American states did not welcome this reversion in the distribution of loans. The Dominican Republic protested (IADB 1986: 177): "An attempt to redirect the work of the Bank to other aims or to refashion the [IADB] in the image of other multilateral agencies would strip our regional agency of its identity..." But as Babb (2009: 142) notes in detail, the U.S. would employ capital replenishments as an opportunity to impose its preferences, including an astounding agreement that $25 \%$ of the bank's resources would be committed to policy-based loans emphasizing liberalization and privatization (hence explaining the sudden rise in Fig. 3).

\subsection{Reversion in the politicization of lending}

The IADB also experienced significant politicization of lending decisions, in direct contrast to the original intensions of the founding coalition. Particularly contentious was the IADB's suspension of financing to Nicaragua from 1983 to 1988 in response to its government's relationship with the Soviet Union. The U.S. began by simply not attending meetings to discuss loans to Nicaragua, thereby denying quorum (Leogrande 1996: 334). U.S. Secretary of State George Schultz followed with thinly veiled threats to deny further capital if Nicaraguan loans were approved. Such direct lobbying was unprecedented, and, to the consternation of Nicaragua, successful. Their dissatisfaction was clear:

...the events of the past year have confirmed our fears and now oblige us to speak up even more emphatically about the need to reaffirm and defend the multilateral and apolitical character of this institution...The negation of this principle would mark the beginning of the end-slowly but surely-of our regional bank as originally conceived and its transformation into a financial agency of a certain country and a political tool for exerting bilateral pressure (IADB 1986: 78, emphasis added).

The rest of the founding coalition would echo this message when the Bank denied loans to Panama in 1988 to sanction the regime of Manuel Noriega (see, e.g., IADB 1988: pp. 63 [Honduras] and 76 [Paraguay]). Mexico warned that such politicization violated the spirit of the bank's original purposes, and Argentina lamented that the IADB "is not contributing to the solution of our problems and in fact forms part of them" (Ibid: pp. 113 and 121, respectively).

\subsection{Reversion in conditionality}

Finally, The IADB underwent reversion in its policies toward conditionality. By the end of the 1980s the bank's attitude toward conditions was indistinguishable from that of the IBRD in the 1950s. This was the result of direct pressure from the United States and like-minded European members (IADB 1985: 124; IADB 1986: 135; IADB 1988:

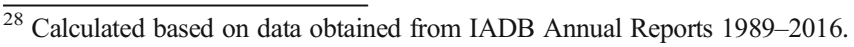




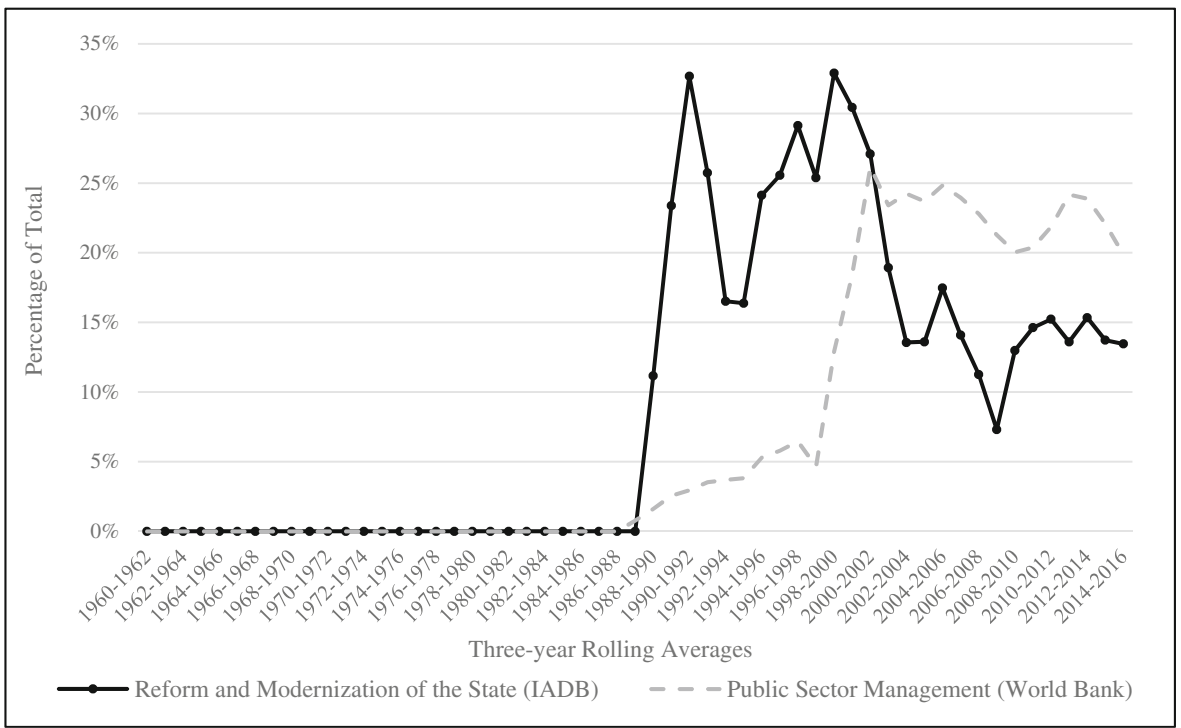

Data collected from IADB Annual Reports (1960-2016) and World Bank Annual Reports (1960-2016). Both the IADB and World Bank have made numerous alterations to how they categorize sectors over time without providing full re-calculations of previous years' statistics. Therefore, this Figure may underestimate the number of Policy-based loans made over time.

Fig. 3 Policy-based lending at the IADB and World Bank

124). Latin American states' dissatisfaction was palpable; the Dominican Republic, Honduras, Nicaragua, Costa Rica, Uruguay, Peru, Mexico, Argentina and Ecuador all directly protested the increasing use of conditions at Annual Meetings in the 1980s (IADB 1985, 1986, 1988).

Once again, however, governance concessions accepted for outside capital undermined the founding coalition's power to resist. Every regional borrowing state is a member of a voting constituency, and interviews with current and former Executive Directors confirmed that states with little voting power have to work much harder to exert their influence (Interviews \#7, 9). One former representative of a small regional state, speaking under the condition of anonymity, described the diplomatic skill necessary to ensure loan approval:

A meeting is like an iceberg. The tip of the iceberg is only $20 \%$; most of it is under the water. In a meeting, what happens in the room is only $20 \%$ and $80 \%$ happens outside and before the meeting. I try to choreograph the deliberations in the meeting by careful and extensive discussions with each and every director before the Board or committee meeting. An example of this technique was a situation in which the UK Director would not agree to support a certain project. The UK Director takes his instructions from DFID [UK Department for International Development]. DFID in London is going to take their cue from DFID in the [region], based in [country X]. I called a contact at DFID [in country X] and explained the importance of the project and requested their intervention in support of the project; [I said to my contact,] 'You know people at DFID in 
London. We need a message sent to the Director here through London.' So, they sent a message to London saying we support this project in [country Y] and London DFID told the Director, 'We want this to go through.' So the director did not oppose the project at the Board meeting because he got the message. $\mathrm{He}$ doesn't know that to this day! (Interview \#9)

The necessity of exerting such an effort is a derivative of the bank's corporate governance structure. And over time this structure has undermined the capacity of Latin American states - especially small states - to resist reversion in the bank's policy toward conditionality.

\subsection{Countervailing creation: Bank of the South}

In 2006 Venezuelan President Hugo Chávez announced plans to create a Bank of the South (BancoSur). The Bancosur was enthusiastically supported by Argentina, Bolivia, Ecuador, Paraguay and Uruguay (Páez Pérez 2010: 167). In 2007 the BancoSur was officially founded with the 'Quito Agreement,' and, with the added membership of Brazil, received an initial capitalization of $\$ 20$ billion two years later (Ibid).

The BancoSur is a direct reaction to its founding coalition's dissatisfaction with the distribution and procedures of the IADB and World Bank, or, as Chávez described them, the "tools of Washington" (Lendman 2007). Pedro Pérez, Ambassador for the Ecuadorian Government, elaborated on the need for a countervailing alternative:

A significant number of development banks were linked to the industrialization through import-substitution project that had been in place in the region since the 1970s and involved both the World Bank and the Inter-American Development Bank. Paradoxically these institutions have gradually moved away from their original purpose..." (Jarrin and Buxton 2011, emphasis added).

In response to this reversion, the BancoSur will seek to address its founding members' dissatisfaction with the status quo. In regard to procedure, its headquarters are in Caracas, the original location envisioned by the founding coalition of the IADB in the 1950s. Further, the bank intends to exclude non-regional states and institute one nation-one vote representation, thereby protecting the voice of smaller members (BancoSur 2007). And, finally, it will forbid policy-based lending and the attachment of social or economic conditions to loans (McElhinny 2007: 4). In sum, the BancoSur is a typical example of countervailing creation.

\subsection{Countervailing creation: The Andean Development Corporation}

The BancoSur is not the only MDB created as a countervailing alternative to the World Bank and IADB. In 1970 a group of Latin American countries located in the Andean sub-continent established the Andean Development Corporation (CAF). The CAF was designed to differ from the World Bank and IADB in three important ways: borrowers would be in control; dual-class stock would protect regional members' voting power; and the distribution of 
lending would focus on the specific needs of Andean states (Humphrey 2016: 103). It was, in other words, an instance of countervailing creation. After a long period of struggle, the CAF grew quickly in the late 1980s and early 1990s under the leadership of Luis Enrique García (Ibid: 106), and is now one of the largest sources of MDB financing in Latin America.

At first glance, the success of the CAF would appear to challenge this article's theoretical model. But a closer examination indicates otherwise. Unlike the IADB and $\mathrm{ADB}$, the CAF originally sought funding from private lenders and other MDBs (Humphrey 2016: 103-4). But by the end of the 1970s the bank's financial situation was dire (Vega 2015: 81). Rather than allow the institution to fail, the founding coalition sought financing from outside countries. Specifically, the CAF admitted non-Andean Latin American states with superior credit ratings and capital reserves (e.g., Mexico, Brazil and Argentina), enhancing the capacity of the institution itself to raise capital (Ibid: 106). García also planned to admit major industrialized countries, and in the $2000 \mathrm{~s}$ Spain and Portugal joined. The acquisition of non-regional members, in combination with García's efforts to acquire ratings from major private credit agencies, led to a remarkable turnaround in the CAF's fortunes (Ibid: 107).

Has the CAF experienced reversion? In the early 1990s the bank began investing heavily in infrastructure, an area that was not originally considered a priority (García 2015: 6). Ortiz and Ugarteche (2013: 106) argue that the BancoSur is specifically designed to differ from this sectoral emphasis. Further, the Bank made a conscious decision to rebrand itself as a Latin American, rather than an Andean, institution (García 2015). Procedurally, there is some evidence to suggest reversion in conditionality; Ecuadorian Ambassador Pérez states: "the...CAF and the [IADB] [create] loans that have names like 'Combat Poverty' but in reality are...loans to finance consultations on poverty which tend to be linked to a short list of consultants who basically reproduce the... Washington Consensus" (Jarrin and Buxton 2011). These changes may explain why members of the CAF's founding coalition (e.g., Venezuela and Ecuador) led efforts to create yet another countervailing MDB in the BancoSur.

Overall, however, the CAF's reversion appears relatively moderate in comparison to the ADB and IADB. This is, I posit, attributable to the reduced number of institutional concessions (Table 1) made in return for outside capital. The founding coalition did have to sacrifice significant ownership; as of 2015 their collective shares stood at $65.8 \% .^{29}$ But evidence suggests that they were able to avoid concessions on voting thresholds, constituencies, procedural rules and executive positions. Their ability to do so was likely facilitated by the decision to pursue private and multilateral financing sources for the first ten years of operation. By expanding the range of potential financiers, the CAF may have enhanced its negotiating position. As I address in Section 7, systematically theorizing the effect of private financing sources and holdout time on borrower-contributor negotiating dynamics would be a fruitful avenue for future research.

\footnotetext{
${ }^{29}$ Calculated from CAF (2015).
} 


\section{The Islamic Development Bank}

In December 1973, a coalition of predominantly Muslim states led by the Organization of Arab Petroleum Exporting Countries (OAPEC) established the Islamic Development Bank (IsDB). The IsDB was founded as a countervailing alternative to the World Bank, adopting features and practices that directly addressed its founding coalition's dissatisfaction with the status quo. Unlike the ADB and IADB, the IsDB has not undergone an undesirable reversion in its distribution of lending, politicization of loans or policies toward conditionality. Nor has the Arab region seen the creation of another countervailing institution within the observation period. Thus, the IsDB differs from the previous case studies on the dependent variable for both Hypotheses A and B. What explains this difference, and why have we not seen a proliferation of MDBs in the Arab world since the creation of the IsDB?

\subsection{Dissatisfaction with the World Bank}

By the time the IsDB was founded in 1973, Arab members had developed, like their contemporaries in Asia and Latin America, significant dissatisfaction with the distribution and procedures of the World Bank. ${ }^{30}$ With regard to distribution, the IBRD approved only two loans to the Middle East and North Africa (MENA) in its first 12 years of operation (Kingston 1996: 40-41). The Bank's distributional priorities would be revealed in 1947 when Iranian economist Abolhassan Ebtehaj approached the bank for a $\$ 250$ million-dollar loan to support a seven-year industrialization plan. The IBRD denied the loan, citing (a) the necessity of prioritizing the reconstruction of Europe and (b) reservations about Iran's political stability and repayment capacity (Kapur et al. 1997: 104). Ebtehaj was enraged by the decision, later recalling to a British official: "it was now quite clear that the International Bank was simply a device for helping the European powers and not the impoverished peoples of the Middle East who really needed it" (Bostock and Jones 1989: 101).

Arab states were also dissatisfied with the procedures of the IBRD. On the eve of the IsDB's creation, the MENA region collectively held just $6.76 \%$ voting power in the Bank (IBRD 1974). The U.S. and U.K. individually held $23 \%$ and $9 \%$, respectively (Ibid). Further, every Arab state was part of a voting constituency. This lack of voice was not for want of effort. The transcripts of the Bretton Woods conference in 1944 reveal that Iran, for example, protested its voting share: "In spite of the very eloquent and moving speech of the United States delegate, on behalf of the Iranian delegation I wish to state that the quota proposed for my country is entirely unsatisfactory" (Lowrey 2012). Egypt and Iraq also put forward multiple motions for the IBRD to have a separate Executive Director for the Middle East, but these initiatives were consistently denied (U.S. State Department 1948: 508, 913-914, 1086).

Dissatisfaction with the IBRD's corporate governance structure was also expressed in annual meetings of the Bank's Board of Governors. In 1965, for example, the Pakistani delegation protested the use of 'tied aid,' i.e., lending that requires the

\footnotetext{
${ }^{30}$ It should be noted that the IsDB aims to facilitate the development of all 'Muslim states,' and therefore its membership extends to the predominantly Muslim countries of Southeast Asia. Nevertheless, the original push for its creation came from the Middle East and North Africa (MENA or the 'Arab world').
} 
procurement of goods and services from a particular country: "The problems of this character are only examined by exclusive clubs of the developed nations without any representation from the borrower countries. I submit, that the time has come when many of these arrangements need to be reviewed..." (IBRD 1965: 61). Egypt would echo this dissatisfaction in 1966 when protesting the politicization of lending decisions: "This sorrowful state of affairs is, in the mind of a lot of people, largely due to the inadequacy of the structure of the World Bank as a financier of economic development" (IBRD 1966: 65, emphasis added). Arab states also expressed their dissatisfaction with the lack of Arab individuals in senior positions at the Bank (Kapur et al. 1997: 979). And, in 1965, Algeria called for a review of the World Bank's procedures "so that they may be better adapted to the needs of many underdeveloped countries" (IBRD 1965: 16). ${ }^{31}$

Loans to the Middle East were also subject to politicization by the World Bank's largest shareholders. A remarkable example of this danger was the Egyptian 'Aswan High Dam' project of 1956. The High Dam would divert the Nile, providing Egypt with enough water to increase the country's agricultural income by an estimated $45 \%$ in 18 years (Mason and Asher 1973: 432-33). This would allow Egypt to keep pace with its rapid population growth; the U.S. State Department concluded, "Without the High Aswan Dam, the outlook for Egypt appears hopeless" (Alterman 2002: 109). British support dwindled, however, when Egyptian President Gamal Nasser supported Arab nationalist movements in Algeria, Iraq and Jordan (Mason and Asher 1973: 628). The U.S. also had concerns over Nasser's relationship with the Soviet Union (Ibid: 638). The final straw was reached in May 1956 when Egypt gave diplomatic recognition to the Communist People's Republic of China (Ibid: 639). The U.S. withdrew its support for the project, and any hope of World Bank financing subsequently dissipated. Frustrated with the Bank's intransigence, Nasser accepted funding from the Soviet Union and appropriated the assets of the Suez Canal Company. These actions led to a tripartite invasion by France, Israel and the United Kingdom (i.e., the Sinai War).

\subsection{Countervailing creation: The Islamic Development Bank}

As the theoretical model anticipates, dissatisfied Arab states first attempted to change the institution. Newly wealthy oil-producing states offered to increase their contributions in return for procedural and distributional changes (Kapur et al. 1997: 974-76). These offers were, however, ultimately rejected, leaving the founding coalition with only one option: create a countervailing alternative. The concept of the IsDB originated in the Organization of Islamic Cooperation (OIC), established in 1969 to facilitate political and economic coordination among Muslim states. The OIC was largely an expression of anti-colonialism, and represented a repudiation of economic dependency on Colonial powers and Western firms (Malik 1989). Arab states realized that "economic independence is crucial for political independence," and the OIC subsequently

\footnotetext{
${ }^{31}$ The region's lack of representation within the IBRD also undermined Arab states' capacity to protest the imposition of obstructive conditions. Syria, for example, could not access financing because it was unable to demonstrate its creditworthiness. Egypt protested these requirements in 1953, and the British government prevented the Bank from even considering aid to Jordan despite the IBRD's own evaluation that "Jordan is clutching at the Bank as a last straw." See Kingston (1996: 41); Kapur et al. (1997: 61); IBRD (1953: 37).
} 
became a springboard for regional trade agreements and multilateral institutions (İhsanoğlu 2010: 19).

The most substantial initiative of the OIC was the establishment of the IsDB as a countervailing alternative to the World Bank. The IsDB personified the spirit of its parent organization, as expressed by the bank itself:

The Islamic Development Bank is an expression of the genuine desire of OIC member countries for cooperation and solidarity, when it appeared in the past decade that the international economic order, set up after the Second World War, had to be reformed and restructured (IsDB 1984: 5, emphasis added).

Discussions of the IsDB began in 1970 during the Second Conference of Foreign Ministers of Muslim Countries of the OIC (Meenai 1989: 2). The initial negotiations took place in the context of OAPEC's newfound negotiating power in the oil industry, culminating in the organization's decision to raise prices by $70 \%$ in 1973 (Schwadran 1986: 56). With regard to distribution, the IsDB would supply much-needed capital investment to predominantly Muslim states in the MENA region. Members of OAPEC could invest their petrodollars in profitable and secure development projects, benefiting lenders and borrowers simultaneously. The IsDB Articles of Agreement state that the bank's primary function is to provide financing for 'economic and social infrastructure,' and the bank's intension was to concentrate on infrastructure, energy, agriculture and social projects (Meenai 1989: 66).

The IsDB was also envisioned to address its founding coalition's dissatisfaction with the procedures of the IBRD. Most importantly, it would not attach political or economic conditions to loans beyond the terms of repayment. And with regard to corporate governance, the founding coalition anticipated that the IsDB would preserve their voice by excluding non-OIC states: "The IsDB has no non-regional members. The IsDB is an institution established by the Ummah [Islamic Nations], for the Ummah and operated and managed by the Ummah" (IsDB 2017).

\subsection{No acceptance of outside financing}

Unlike the ADB and IADB, the founding coalition of the IsDB had no need to approach non-regional states for assistance. Indeed, the OAPEC members initiated the creation of the institution, and were able to finance it independently as a result of their newfound oil revenues. The largest oil-producing countries would obtain substantial voting power in return for their contributions. Saudi Arabia, one of the original proponents of the bank, would acquire a $23 \%$ voting share, and the bank's headquarters were established in Jeddah. The influence of Saudi Arabia was mitigated, however, by the necessity of a simple majority for the approval of loans and alterations of policy. This ensured that no one member could employ de facto veto power.

\subsection{The distribution of loans by sector}

The IsDB's distribution of loans by sector has not undergone an undesirable reversion to the status quo model. As noted above, the founding coalition of the IsDB desired that 
the bank focus on transportation infrastructure, energy, agriculture and social infrastructure (education, health and water/sanitation). The IsDB's lending by sector has consistently matched the priorities established by its founding coalition, and have grown to encompass over $90 \%$ of the Bank's portfolio. Thus, with regard to distribution by sector, the IsDB has actually become more similar to the founding coalition's original conception over time, in direct contrast to the undesirable reversion of the $\mathrm{ADB}$ and IADB. ${ }^{32}$

Further, a comparison of the IsDB and World Bank's distribution of lending indicates substantial divergence, especially since the 1990s (Fig. 4). Unlike the World Bank, the IsDB has never invested in policy-based lending, in accordance with its members' aversion to intrusive alterations of domestic institutions (IsDB 2016). The IsDB has also diverged considerably from the World Bank and other MDBs in its proportion of lending to the financial sector. This policy is motivated by Islam's religious prohibition of excessive speculation (Saeed 1996; Damak and Plantagie 2015: 69). IsDB financial loans have averaged only $4.8 \%$ of the bank's lending portfolio since inception, compared to, for example, approximately $12 \%$ at the ADB in the same period. ${ }^{33}$ The IsDB also had no significant exposure to asset- and mortgage-backed securities in the years prior to the 2008 crisis. This differs considerably from the IADB, World Bank and ADB, whose portfolios had exposure rates of approximately $50 \%, 20 \%$ and $5 \%$, respectively, in 2007 (Morales et al. 2008: 7). ${ }^{34}$ Qualitative evidence also indicates that IsDB decisions on individual projects often diverge from the World Bank's. In 1984, for example, the IsDB provided Niger with financing for an infrastructure project that the World Bank rejected (Wilson 1990: 211). And in 1998, when the World Bank refused funding to Pakistan in response to its testing of nuclear weapons, the IsDB infuriated the United States by stepping in to fill the gap (Sfeir and King 2007: 310).

\subsection{Conditionality and politicization}

The IsDB has also avoided a reversion with regard to conditionality. It has consistently been the bank's policy to attach no political or economic conditions to loans beyond repayment. The bank was also unaffected by the rise of environmentalism in the 1990s (O'Keefe 2004). In its 1992 annual report the bank warned, "international preoccupation with environmental protection might be one-sided and to the determinant of developing countries" (Deegan 1996: 176). Recent events corroborate that the IsDB's policy toward environmental sustainability diverges from that of Western-dominated MDBs. In 2013 the U.S., U.K. and various Nordic countries announced that they would no longer support MDB projects involving coal-powered technology (White House 2013). The IsDB, which does not include these countries as members, approved a $\$ 220$ million project for a coal-powered energy plant in Pakistan one year later (Pakistan Today 2014). The IsDB is not, of course, immune from politics. To the contrary, one study finds that Sunni regime states receive favorable treatment in aid allocation (Hernandez and Vadlamannati 2017). But, integrally, politicization has not contradicted

\footnotetext{
32 This trend is consistent with Shushan and Marcoux's (2011) finding that Arab bilateral donors and multilateral agencies have regularly concentrated financing toward infrastructure, energy and water.

${ }^{33}$ Calculations performed based on three-year rolling averages for each bank from 1975 to 2016 .

34 The IADB reportedly lost $\$ 1.9$ billion in 2008 as a result (Stern 2009).
} 


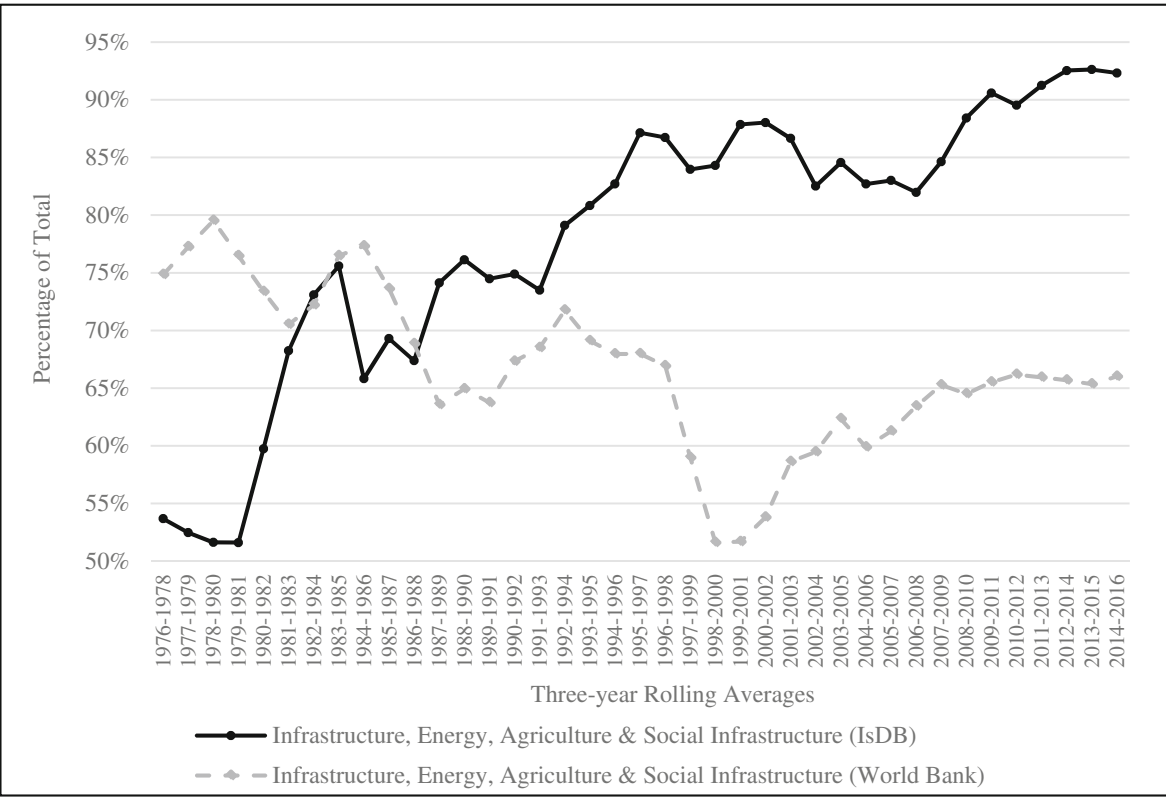

Data collected from IsDB (2016) and World Bank Annual Reports (1976-2016).

Fig. 4 Differences in lending priorities at the IsDB and World Bank, 1976-2016

the original intensions of the founding coalition of oil-producing states that continued to dominate the institution. This lack of reversion has provided no impetus for the creation of yet another countervailing institution by members of the same coalition.

\section{Conclusion}

"To do the same thing and expect a different result, [that's] Einstein's definition of insanity. If you want something different go and do something different!"

\section{Interviewee \#23 on the New Development Bank}

The history of multilateral development banking is replete with attempts to 'do something different.' But as this article has sought to demonstrate, countervailing MDBs often deviate from their original purpose, paradoxically coming to resemble the dissatisfactory status quo institution over time. This reversion contradicts the intensions of the founding states, leading members to create yet another countervailing alternative. This cyclical pattern conjures images of Sisyphus pushing his boulder up the mountain. The question is: why does he allow the boulder to roll back down? What, in other words, explains the repetitive and undesirable reversion of the boulder?

The theoretical model put forward in this article argues that the answer is not the gods or any deterministic external force. Rather, it is the result of rational decision- 
making by loss-averse coalitions with an imperfect ability to anticipate the future consequences of their present decisions. Consistent with Hypothesis A, the empirical evidence suggests that MDBs created by capital-poor founding coalitions are more likely, ceritus paribus, to experience reversion. The ADB and IADB changed in direct contrast to their founders' original intensions on three key measures: distribution of lending by sector; politicization of lending decisions; and loan conditionality. And, consistent with Hypothesis B, members of the founding coalition in both regions created yet another countervailing alternative in response (the AIIB in Asia and the BancoSur and CAF in Latin America). The CAF exhibits a similar pattern, but the extent of its reversion was relatively moderate. The founding coalition accepted fewer institutional concessions in return for outside capital than the founders of the ADB and $\mathrm{IADB}$, and, therefore, maintained a relatively strong future negotiating position. This is consistent with the model's expectation that there is a negative correlation between the number of institutional concessions accepted in the past and the capacity of the founding coalition to resist reversion in the future. Finally, the IsDB, founded by a capital-rich coalition, did not experience reversion. Nor has the MENA region seen the creation of another countervailing MDB within the observation period.

This article has argued that the conditions under which countervailing creation occurs (in this case, the capital endowment of the founding coalition) affects (a) how institutions change over time, and (b) the likelihood of further proliferation. In so doing, the model illustrates that the rational actions of states in the past can lead to seemingly irrational institutional change in the future. This argument is a complementary extension of existing frameworks that seek to explain how and why states create countervailing international organizations (Jupille et al. 2013; Morse and Keohane 2014). Further, the simultaneous assumptions of loss aversion and bounded rationality contribute to our understanding of how behavioral economics can help International Relations theorists better understand strategic interaction and institutional dynamics (see Stein 2017).

There are three clear avenues for future research. First, it would be prudent to evaluate the model's capacity to explain the creation and development of other countervailing MDBs such as the African Development Bank. Doing so is essential to fully evaluating its explanatory capacity. Second, the model may be applicable to other types of countervailing organizations. Potential examples include the Chiang Mai Initiative, created as a regional alternative to the International Monetary Fund (Eichengreen 2012), and the decision of employees to leave their firm and create rival start-ups. Before assessing these potential applications, it may prove useful to formally model the strategic interactions discussed in this article.

Finally, future extensions of the model may benefit from systematically theorizing factors not directly considered here. The founders of the CAF, for example, appear to have enhanced their negotiating position vis-à-vis non-regional entrants by first pursuing alternative financing sources. How exactly does the presence of private financiers affect bargaining between borrowing and contributing member states? Can founding coalitions improve their future negotiation position by holding out (i.e., not admitting non-regional states) for longer periods of time? By investigating these (and other) questions, we can further improve our understanding of MDB proliferation and, more generally, the strategic dynamics of countervailing creation. 
Acknowledgements This project would not have been possible without the guidance and support of Professor Walter Mattli. I am also grateful to Janina Dill, Axel Dreher, Ryan Harvey, Rachel Myrick, Jack Seddon, Max Smeets, Ngaire Woods, three anonymous reviewers, and my former graduate cohort for comments on earlier drafts. I also thank Annette Idler, Dominic Johnson, Anette Stimmer and attendants of the Graduate Seminar at the University of Oxford's Department of Politics and International Relations for their helpful suggestions. Finally, I am indebted to the countless administrative staff, librarians and, especially, interviewees for generously providing their time to assist this study. This project received financial assistance from St. John's College, University of Oxford.

Open Access This article is distributed under the terms of the Creative Commons Attribution 4.0 International License (http://creativecommons.org/licenses/by/4.0/), which permits unrestricted use, distribution, and reproduction in any medium, provided you give appropriate credit to the original author(s) and the source, provide a link to the Creative Commons license, and indicate if changes were made.

\section{References}

Abbas, S. (1956). Capital Requirements for the Development of South and South-East Asia. Groningen: JB Wolters.

Abbott, K. W., \& Snidal, D. (1998). Why States Act through Formal International Organizations. The Journal of Conflict Resolution, 42(1), 3-32.

ADB. (1966). Agreement Establishing the Asian Development Bank (ADB Charter). Manila. https://www.adb. org/sites/default/files/institutional-document/32120/charter.pdf

ADB. (1967). Annual Report. Manila. https://www.adb.org/sites/default/files/institutional-document/32208 /adb-ar-1967.pdf

ADB. (1990). Annual Meeting of the Board of Governors. New Delhi.

ADB. (1991). Annual Meeting of the Board of Governors. Vancouver.

ADB. (2006). Annual Meeting of the Board of Governors. Hyderabad.

ADB. (2007). Annual Meeting of the Board of Governors. Kyoto.

ADB. (2009a). Infrastructure for a Seamless Asia. Manila. https://www.adb. org/sites/default/files/publication/159348/adbi-infrastructure-seamless-asia.pdf

ADB. (2009b). Reflections \& Beyond. Manila: Asian Development Bank.

ADB. (2009c). Annual Meeting of the Board of Governors. Bali.

ADB. (2011). Annual Meeting of the Board of Governors. Hanoi.

ADB. (2012). Annual Meeting of the Board of Governors. Manila.

ADB. (2013). Annual Meeting of the Board of Governors. New Delhi.

ADB. (2014). Annual Meeting of the Board of Governors. Astana.

ADB. (2016). Asian Development Bank 2016 Sustainability Report: Investing for an Asia and the Pacific Free of Poverty. Manila. https://www.adb.org/sites/default/files/institutional-document/183043/sr2016.pdf

Allison, G., \& Zelikow, P. (1999). Essence of Decision: Explaining the Cuban Missile Crisis (2nd ed.). New York: Longman.

Alterman, J. (2002). Egypt and American Foreign Assistance 1952-1956. New York: Palgrave Macmillan.

Andrés, L., Biller, D., \& Dappe, M. (2014). Infrastructure Gap in South Asia: Infrastructure Needs, Prioritization, and Financing (No. 7032). Washington, D.C. http://documents.worldbank. org/curated/en/504061468307152462/Infrastructure-gap-in-South-Asia-infrastructure-needsprioritization-and-financing

Avalle, O. A. (2005). The multilateral development banks in Latin America and the Caribbean region. Vermont Journal of Environmental Law, 6(2), 193-212.

Babb, S. (2009). Behind the Development Banks. Chicago: University of Chicago Press.

BancoSur. (2007). Founding Charter of the Bank of the South. Caracas. http://www.choike. org/documentos/Acta fundacion bco del sur.pdf

Basílio, M. S. (2014). The Determinants of Multilateral Development Banks' Participation in Infrastructure Projects. Journal of Infrastructure Development, 6(2), 83-110.

Bennett, A., \& Elman, C. (2006). Complex causal relations and case study methods: The example of path dependence. Political Analysis, 14(3), 250-267. 
Birdsall, N. (2014). The World Bank and Inter-American Development Bank: Fit for 21st Century Purpose? Washington, D.C. https://www.files.ethz.ch/isn/179562/worldbank-idb-fit-21st-century.pdf

Bostock, F., \& Jones, G. (1989). Planning and Power in Iran: Ebtehaj and Economic Development under the Shah. New York: Routledge.

Bulmer-Thomas, V. (2014). The Economic History of Latin America since Independence. Cambridge: Cambridge University Press.

CAF. (2015). Investor Presentation. https://www.caf.com/media/2814887/caf-ifin-investor_presentation_june_2015.pdf

Camerer, C., \& Loewenstein, G. (2004). Behavioral Economics: Past, Present, Future. In C. Camerer, G. Loewenstein, \& M. Rabin (Eds.), Advances in Behavioral Economics (pp. 3-51). New York: Princeton University Press.

Chaudhry, P. K., Kelkar, V. L., \& Yadav, V. (2004). The evolution of "homegrown conditionality" in India: IMF relations. Journal of Development Studies, 40(6), 59-81.

Cho, L., \& Katz, S. (2001). A Northeast Asian Development Bank? NIRA Review, 8(1), 41-47.

Culpeper, R. (1997). Titans or Behemoths: The multilateral development banks (5th volume). Boulder: Lynne Rienner.

Damak, M., \& Plantagie, J. W. (2015). Islamic Finance Outlook 2016 Edition. https://www.spratings. com/documents/20184/86966/Islamic_Finance_Outlook_2016_v2/4d9d6fd9-3b11-4ae2-9168-13ee2543 b73b

de Búrca, G. (2016). Contested or competitive multilateralism? A reply to Julia C. Morse and Robert O. Keohane. Global Constitutionalism, 5(3), 320-326.

De Cremer, D., \& Tyler, T. (2005). Managing Group Behavior: The Interplay Between Procedural Justice, Sense of Self, and Cooperation. In M. Zanna (Ed.), Advances in Experimental Psychology (37th ed., pp. 151-218). London: Elsevier Academic Press.

Deegan, H. (1996). Third Worlds: Politics in the Middle East and Africa. London: Taylor \& Francis.

Dell, S. (1972). The Inter-American Development Bank. New York: Praeger.

DeWitt, R. (1977). The Inter-American Development Bank and Political Influence: With Special Reference to Costa Rica. New York: Praeger.

Diamond, W. (1957). Development Banks. Baltimore: Johns Hopkins Press.

Diaz-Bonilla, E., \& Campo, M. (2010). A Long and Winding Road: The Creation of the Inter-American Development Bank. Lulu: University of Manchester.

Dosman, E. J. (2008). The Life and Times of Raul Prebisch. Montreal: McGill-Queen's University Press.

EBRD. (2012). Multilateral Development Bank Principles to Support Sustainable Private Sector Operations. London. http://www.ebrd.com/downloads/news/mdb.pdf

ECAFE. (1964). Report of the Ministerial Conference on Asian Economic Cooperation. Bangkok.

ECAFE. (1965). The Asian Development Bank and Trade Liberalization (No. 2). Bangkok.

ECAFE. (1966). Report of the Second Ministerial Conference on Asian Economic Co-operation, Final Act of the Conference of Plenipotentiaries on the Asian Development Bank, and Report of the Preparatory Committee on the Asian Development Bank (No. 4). Bangkok.

Eichengreen, B. (2012). Regional Financial Arrangements and the International Monetary Fund (No. 394). Tokyo. Regional Financial Arrangements and the International Monetary Fund.

Fawcett, J., \& Downs, F. (1986). The Relationship of Theory and Research. Norwalk: Appleton-CenturyCrofts.

Follesdal, A. (2016). Implications of contested multilateralism for global constitutionalism. Global Constitutionalism, 5(3), 297-308.

García, L. E. (2015). Comparative Advantages and Challenges of Regional Development Banks: the CAF experience. London. http://eprints.lse.ac.uk/65200/1/LSE-GSU-Policy-Brief-2-2015-(Garcia).pdf

Gärling, T., Karlsson, N., Romanus, J., \& Selart, M. (1997). Influences of the past on choices of the future. In R. Ranyard, W. Ray Crozier, \& S. Ola (Eds.), Decision making: Cognitive models and explanations (pp. 167-188). London: Routledge.

Genschel, P., \& Plümper, T. (1997). Regulatory competition and international co-operation. Journal of European Public Policy, 4(4), 626-642.

Gerring, J. (2008). Case Selection for Case-Study Analysis: Qualitative and Quantiative Techniques. In J. Box-Steffensmeier, H. Brady, \& D. Collier (Eds.), The Oxford Handbook of Political Methodology (pp. 645-684). Oxford: Oxford University Press.

Gutner, T. (2002). Banking on the Environment: Multilateral Development Banks and their Environmental Performance in Central and Eastern Europe. Cambridge: MIT Press. 
Hall, P. (2010). Historical Institutionalism in Rationalist and Sociological Perspective. In J. Mahoney \& K. Thelen (Eds.), Explaining Institutional Change: Ambiguity, Agency, and Power. Cambridge: Cambridge University Press.

Harris, W. (1997). On "scope conditions" in sociological theories. Social and Economic Studies, 46(4), 123127.

He, A. (2016). China in the International Financial System: A Study of the NDB and the AIIB. https://www. cigionline.org/sites/default/files/cigi_paper_no.106.pdf

Hernandez, D., \& Vadlamannati, K. (2017). Politics of religiously motivated lending: An empirical analysis of aid allocation by the Islamic Development Bank. Journal of Comparative Economics, 45, 910-929.

Hirschman, A. (1972). Exit, Voice, and Loyalty. Cambridge: Harvard University Press.

Huang, P. (1975). The Asian Development Bank. New York: Vantage Press.

Humphrey, C. (2016). The Invisible Hand: Financial Pressures and Organisational Convergence in Multilateral Development Banks. Journal of Development Studies, 52(1), 92-112.

Humphrey, C., \& Michaelowa, K. (2013). Shopping for Development: Multilateral Lending, Shareholder Composition and Borrower Preferences. World Development, 44, 142-155.

IADB. (1959). Agreement Establishing the Inter-American Development Bank. Washington, D.C. http://idbdocs.iadb.org/wsdocs/getdocument.aspx?docnum=781584

IADB. (1960). Annual Meeting of the Board of Governors. San Salvador.

IADB. (1985). Annual Meeting of the Board of Governors. Vienna.

IADB. (1986). Annual Meeting of the Board of Governors. San Jose.

IADB. (1988). Annual Meeting of the Board of Governors. Caracas.

IBRD. (1953). IBRD Annual Meeting. Washington, D.C.

IBRD. (1959). IBRD Annual Report. Washington, D.C.

IBRD. (1965). IBRD Annual Meeting. Washington, D.C.

IBRD. (1966). IBRD Annual Meeting. Washington, D.C.

IBRD. (1974). IBRD Annual Report. Washington, D.C.

İhsanoğlu, E. (2010). The Islamic world in the new century: The organisation of the Islamic conference, 19692009. London: Hurst \& Company.

IsDB. (1984). The Islamic Development Bank: Activities and Achievements. Jeddah: Islamic Development Bank.

IsDB. (2016). Islamic Development Bank Online Lending Data. http://www.isdb. org/irj/go/km/docs/documents/IDBDevelopments/Internet/English/IDB/CM/IDBGroupData/ CountryApprovals_Main.htm

IsDB. (2017). Principles of Operations. Islamic Development Bank. http://www.isdb. org/irj/portal/anonymous?NavigationTarget=navurl://91b765e29a0bbf4da579f0c9bbf5f83f

Izotov, D. (2014). Economic Development of the Russian Far East and the Northeast Asian Development Bank (NEADB). In L. Cho \& C. Jae Lee (Eds.), Financing Economic Integration and Functional Cooperation for Northeast Asia: A Multilateral Financial Institution. Korea Institute for International Economic Policy: Seoul.

Jarrin, S., \& Buxton, N. (2011). Financial Governance Beyond the Crisis: Creating an Innovative Financial Architecture in Latin America. Amsterdam. https://www.tni.org/files/PedroPaezInterview-en-final.pdf

Jupille, J., Mattli, W., \& Snidal, D. (2013). Institutional Choice and Global Commerce. Cambridge: Cambridge University Press.

Kahneman, D., \& Tversky, A. (1979). Prospect Theory : An Analysis of Decision under Risk. Econometrica, 47(2), 263-292.

Kahneman, D., Knetsch, J. L., \& Thaler, R. H. (1990). Experimental Tests of the Endowment Effect and the Coase Theorem. Source Journal of Political Economy, 98(6), 1325-1348.

Kahneman, D., Knetsch, J. L., \& Thaler, R. H. (2008). The Endowment Effect: Evidence of Losses Valued More than Gains. In C. Plott \& V. Smith (Eds.), Handbook of Experimental Economics Results (Vol. 1, pp. 939-948). North Holland.

Kapur, D., Lewis, J., \& Webb, R. (1997). The World Bank: Its First Half-Century (1st ed.). Washington, D.C.: Brookings Institute.

Katz, S. (1996). A Northeast Asian Development Bank. In Sixth Annual Meeting of the NEAEF. Northeast Asia Economic Forum.

Katznelson, I., \& Weingast, B. (2005). Preferences and Situations: Points of Intersection Between Historical and Rational Choice Institutionalism. New York: Russell Sage Foundation.

Keohane, R. O., \& Morse, J. C. (2016). Reply to critics: Contribution to Global Constitutionalism Symposium. Global Constitutionalism, 5(3), 344-350. 
Kingston, P. (1996). Britain and the Politics of Modernization in the Middle East 1945-1958. Cambridge: Cambridge University Press.

Kirby, S. (1950). Some Political Aspects of Far Eastern Economic Development (No. 4). New York.

Koremenos, B., Lipson, C., \& Snidal, D. (2001). The Rational Design of International Institutions. International Organization, 55(4), 761-799.

Krasner, S. D. (1981). Power structures and regional development banks. International Organization, 35(2), 303-328.

Krasner, S. D. (1985). Structural Conflict: The Third World against Global Liberalism. Berkeley: University of California.

Kreuder-Sonnen, C., \& Zangl, B. (2016). Varieties of contested multilateralism: Positive and negative consequences for the constitutionalisation of multilateral institutions. Global Constitutionalism, 5(3), $327-343$.

Lendman, S. (2007). The Bank of the South: An Alternative to IMF and World Bank Dominance. Centre for Research on Globalization. https://www.globalresearch.ca/the-bank-of-the-south-an-alternative-to-imfand-world-bank-dominance/7207

Leogrande, W. M. (1996). Making the Economy Scream: U.S. Economic Sanctions against Sandinista Nicaragua. Third World Quarterly, 17(2), 329-348.

Levy, J. (2013). Psychology and Foreign Policy Decision-Making. In L. Huddy, D. Sears, \& J. Levy (Eds.), The Oxford Handbook of Political Psychology (2nd ed., pp. 301-323). Oxford: Oxford University Press.

Lind, E., \& Tyler, T. (1988). The Social Psychology of Procedural Justice. New York: Plenum.

Lowrey, A. (2012, October 25). Transcript of 1944 Bretton Woods Meeting Found at Treasury. The New York Times. Washington, D.C. http://www.nytimes.com/2012/10/26/business/transcript-of-1944-brettonwoods-meeting-found-at-treasury.html

Lyne, M. M., Nielson, D. L., \& Tierney, M. J. (2009). Controlling coalitions: Social lending at the multilateral development banks. The Review of International Organizations, 4, 407-433.

Magill, F. (1996). Chronology of Twentieth Century History: Business and Commerce. New York: Routledge.

Mahoney, J., \& Thelen, K. (2010). A Theory of Gradual Institutional Change. In J. Mahoney \& K. Thelen (Eds.), Explaining Institutional Change. Cambridge: Cambridge University Press.

Malik, U. (1989). Islamic Economic Cooperation in the South-South Context. In M. Choudhury (Ed.), Islamic Economic Cooperation. New York: Palgrave Macmillan.

Mason, E., \& Asher, R. (1973). The World Bank Since Bretton Woods. Washington, D.C.: Brookings Institute.

McElhinny, V. (2007). A Look into the Bank of the South, due to Launch in December 2007. https://web. archive.org/web/20101217031110/http://globalexchange.org/countries/americas/venezuela/ BankoftheSouth.pdf

Meenai, S. (1989). The Islamic Development Bank. London: Kegan Paul International.

Mikulaschek, C. (2017). Issue linkage across international organizations: Does European countries' temporary membership in the UN Security Council increase their receipts from the EU budget? The Review of International Organizations, 1-28. https://doi.org/10.1007/s11558-017-9289-9.

Mishra, R. (2016). Asian Infrastructure Investment Bank: An Assessment. India Quarterly, 72(2), 163-176.

Morales, R., Santomero, A. M., \& Saunders, A. (2008). Investment Policy Review Panel Report. http://s3. amazonaws.com/propublica/assets/docs/IDB_outside_audit0001.pdf?_ga=2.107423553.2120500283. $1510849481-417818614.1510849480$

Morse, J. C., \& Keohane, R. O. (2014). Contested multilateralism. The Review of International Organizations, 9(4), 385-412.

New York Times. (1951, March 5). Chile's President Hits World Bank. The New York Times.

New York Times. (1955, February 20). Latins Study Bank Plan. The New York Times.

O'Keefe, C. (2004). Values, Institutions and Structures: Islam, democracy and hegemony at the Islamic Development Bank.

Orr, R. (1990). The Emergence of Japan's Foreign Aid Power. New York: Columbia University Press.

Ortiz, I., \& Ugarteche, O. (2013). Bank of the South: Progress and Challenges. http://www.realityofaid. org/wp-content/uploads/2013/02/ROA-SSDC-Special-Report9.pdf

Páez Pérez, P. (2010). The Ecuadorian proposal for a new regional financial architecture. Journal of Post Keynesian Economics, 32(2), 163-173.

Pakistan Today. (2014). IDB approves \$220m for Jamshoro coal power plant. Pakistan Today. https://www. pakistantoday.com.pk/2014/03/31/idb-approves-220m-for-jamshoro-coal-power-plant/

Pan-American Union. (1949). Creation of an Inter-American Bank or Development Corporation or Both. Washington, D.C.: Pan-American Union.

Parízek, M. (2017). Control, soft information, and the politics of international organizations staffing. The Review of International Organizations, 12(4), 559-583. 
Peters, B. G., Pierre, J., \& King, D. S. (2005). The Politics of Path Dependency: Political Conflict in Historical Institutionalism. The Journal of Politics, 67(4), 1275-1300.

Pfeffer, J., \& Salancik, G. (1978). The External Control of Organizations: A Resource Dependence Perspective. New York: Harper \& Row.

Pierson, P. (2000). Not Just What, but When: Timing and Sequence in Political Processes. Studies in American Political Development, 14(1), 72-92.

Pierson, P. (2004). Politics in Time: History, Institutions, and Social Analysis (Vol. 3). Princeton: Princeton University Press http:/www.loc.gov/catdir/enhancements/fy0668/2003063294-d.html.

Prada, F. (2012). World Bank, Inter-American Development Bank, and Subregional Development Banks in Latin America: Dynamics of a System of Multilateral Development Banks. Manila: Asian Development Bank Institute.

Prebisch, R. (1950). The Economic Development of Latin America. Lake Success: United National Economic Commission for Latin America.

Rabe, S. (1988). Eisenhower and Latin America: The Foreign Policy of Anticommunism. Chapel Hill: The University of North Caroline Press.

Rodrik, D. (1996). Why is there Multilateral Lending. Annual World Bank Conference on Development Economics 1995 (pp. 167-205).

Romani, M., Stern, N., \& Stiglitz, J. (2012, April 5). Brics bank is a fine idea whose time has come. The Financial Times. London. https://www.ft.com/content/1770f242-7d88-11e1-81a5-00144feab49a Accessed 1 Dec 2014.

Saeed, A. (1996). Islamic Banking and Interest : A Study of the Prohibition of Riba and its Contemporary Interpretation (1st ed.). Leiden: E.J. Brill.

Sanford, J., \& Fletcher, S. (1998). Multilateral Development Bank's Environmental Assessment and Information Policies: Impact of the Pelosi Amendment. Washington, D.C.: Congressional Research Service.

Schwadran, B. (1986). Middle East Oil Crises Since 1973. Boulder: Westview Press.

Seawright, J., \& Gerring, J. (2008). Case Selection Techniques in Case Study Research. Political Research Quarterly, 61(2), 294-308.

Serrano, E. (1959). Proposal of the delegation of Cuba on the management of the bank. In Inter-American economic and social council specialized committee for negotiating and drafting the instrument of organization of an inter-American financial institution (Accessed at the Library of the Organization of American States). Washington, D.C.: Inter-American Economic and Social Council.

Sfeir, A., \& King, J. (Eds.). (2007). The Columbia world dictionary of Islamism. Translator: King, J. New York: Columbia University Press.

Shushan, D., \& Marcoux, C. (2011). The Rise (and Decline?) of Arab Aid: Generosity and Allocation in the Oil Era. World Development, 39(11), 1969-1980.

Silvia, J. (2011). Dynamic Economic Decision Making: Strategies for Financial Risk, Capital Markets and Monetary Policy. New York: Wiley Finance.

Simon, H. (1997). Models of Bounded Rationality (3rd ed.). Cambridge: MIT Press.

Stein, J. (2017). The Micro-Foundations of International Relations Theory: Psychology and Behavioral Economics. International Organization, 71, S249-S263.

Stern, M. (2009, February 12). Development Bank Wrestles With Toxic Securities Losses. ProPublica. https://www.propublica.org/article/another-institution-wrestles-with-2-billion-in-losses

Strand, J. R. (2003). Measuring Voting Power in an International Institution: the United States and the InterAmerican Development Bank. Economics of Governance, 4(1), 19-36.

Tajfel, H. (1981). Human Groups \& Social Categories. Cambridge: Cambridge University Press.

Thaler, R. H. (1980). Toward a Positive Theory of Consumer Choice. Journal of Economic Behavior \& Organization, 1, 39-60.

Thibaut, J., \& Walker, L. (1975). Procedural Justice. Hillsdale: Erlbaum.

Tsebelis, G. (2002). Veto Players: How Political Institutions Work. Princeton: Princeton University Press.

U.S. State Department. (1948). United Nations Monetary and Financial Conference (1st ed.). Washington, D.C.: U.S. Government Printing Office.

U.S. Treasury Department. (1982). United States Participation in the Multilateral Development Banks in the 1980s. Washington, D.C.

Urpelainen, J., \& Van de Graaf, T. (2014). Your Place or Mine? Institutional Capture and the Creation of Overlapping International Institutions. British Journal of Political Science, 45(4), 799-827.

Valdivieso, R. (1959). Remarks by the chairman of the inter-American economic and social council Rafael Glower Valdivieso, at the inaugural session. In Inter-American economic and social council specialized committee for negotiating and drafting the instrument of organization of an inter-American financial 
institution (Accessed at the Library of the Organization of American States). Washington, D.C.: InterAmerican Economic and Social Council.

Vega, V. R. (2015). From lending in the Andes to thriving in Latin America: CAF's continuity, growth and long-term financing in the region (Doctoral Dissertation). Ontario. http://scholars.wlu.ca/etd

Wagner, R. (1970). United States Policy Toward Latin America. Palo Alto: Stanford University Press.

Walker, N. (2016). Postnational constitutionalism and the challenge of contested multilateralism. Global Constitutionalism, 5(3), 309-319.

Watanabe, T. (1973). Towards a New Asia. Manila: Asian Development Bank.

White, J. (1970). Regional Development Banks. London: Overseas Development Institute.

White House. (2013). Joint Statement by Kingdom of Denmark, Republic of Finland, Republic of Iceland, Kingdom of Norway, Kingdom of Sweden, and the United States of America. Washington, D.C. https:/obamawhitehouse.archives.gov/the-press-office/2013/09/04/joint-statement-kingdom-denmarkrepublic-finland-republic-iceland-kingdo

Wightman, D. (1963). Toward Economic Cooperation in Asia. New Haven: Yale University Press.

Wildau, G., \& Clover, C. (2015, June 29). AIIB launch signals China's new ambition. The Financial Times. Shanghai.

Wilson, D. (1987). A Bank for Half the World: The Story of the Asian Development Bank 1966-1986. Manila: Asian Development Bank.

Wilson, R. (1990). Saudi Arabia: The Islamic Development Bank's Role as a Pan-Muslim Agency. In R. Wilson (Ed.), Islamic Financial Markets. New York: Routledge.

Woods, N. (1999). Good Governance in International Organizations. Global Governance, 5(1), 39-61.

World Bank. (2016a). GDP Ranking Data. https://data.worldbank.org/data-catalog/GDP-ranking-table

World Bank. (2016b). Management's Discussion \& Analysis and Financial Statements (Fiscal Year 2016). Washington, DC. https://openknowledge.worldbank.org/bitstream/handle/10986/24985/210852v2.pdf

Xinhua. (2014, July 16). China Voice: BRICS bank diversifies global finances, not zero-sum game. Xinhuanet.

Xinhua. (2016, January 17). Commentary: AIIB catfish in global financial governance system. Xinhua. Beijing.

Yasutomo, D. (1993). Japan and the Asian Development Bank: Multilateral Aid Policy in Transition. In B. Koppel \& R. Orr (Eds.), Japan's Foreign Aid (pp. 305-340). Boulder: Westview Press.

Young, O. R. (1982). Regime dynamics: the rise and fall of international regimes. International Organization, 36(2), 277-297.

Zinkin, M. (1954). Problems of Economic Development in Asia (Twelfth Conference, Rep. No. 1). Kyoto. 